VERA DE FÁTIMA PADRÃO CORREIA

\title{
AVALIAÇÃO IN VITRO DA CITOTOXICIDADE DO ALENDRONATO DE SÓDIO SOBRE FIBROBLASTOS DE LIGAMENTO PERIODONTAL DE HUMANOS EM CULTURA CELULAR
}

São Paulo 
Vera de Fátima Padrão Correia

Avaliação in vitro da citotoxicidade do alendronato de sódio sobre fibroblastos de ligamento periodontal de humanos em cultura celular

Dissertação apresentada à Faculdade de Odontologia da Universidade de São Paulo, para obter o Título de Mestre, pelo Programa de Pós-Graduação em Odontologia.

Área de Concentração: Endodontia

Orientador: Prof. Dr. Celso L. Caldeira

São Paulo 



\section{FOLHA DE APROVAÇÃO}

Correia VFP. Avaliação in vitro da citotoxicidade do alendronato de sódio sobre fibroblastos de ligamento periodontal de humanos em cultura celular [Dissertação de Mestrado]. São Paulo: Faculdade de Odontologia da USP; 2005.

Data da defesa: / 2005

\section{Banca Examinadora}

Prof.(a) Dr(a): :

Titulação:

Julgamento:

Assinatura:

Prof.(a) Dr(a):

Titulação:

Julgamento:

Assinatura:

Prof.(a) Dr(a).:

Titulação:

Julgamento:

Assinatura:

Prof.(a) $\operatorname{Dr}(\mathrm{a})$.:

Titulação:

Julgamento:

Assinatura:

Prof.(a) Dr(a).:

Titulação:

Julgamento:

Assinatura: 


\section{DEDICATÓRIAS}

Aos meus pais, Antonio e Aurora, que pelo amor e exemplo de vida sempre me ensinaram a lutar e me apoiaram nos meus maiores sonhos.

Aos meus amigos, por tudo o que representam na minha na minha vida e pelo sacrifício, compreensão, carinho e incentivo constantes, que tanto contribuíram para que fosse possível a concretização deste ideal.

Sabendo que nada sou, dedico essa obra a Deus Pai, pela inspiração e força que me permitiram concretizá-la. 


\section{AGRADECIMENTOS}

Ao meu orientador Prof. Dr. Celso L. Caldeira, pela orientação segura, pelo apoio constante, pela dedicação e profissionalismo durante a execução deste trabalho, além da paciência, apoio e confiança a mim conferidos.

A Profa. Dra. Márcia M. Marques, pela solidariedade e presteza com que me conduziu na fase experimental deste trabalho, com seu jeito todo só seu, num momento importante da minha vida.

Aos professores Dr. João Humberto Antoniazzi e Dr. Antonio Carlos Bombana, pela oportunidade de conviver e aprender, cujos ensinamentos jamais esquecerei.

Aos demais professores da Disciplina de Endodontia da FOUSP: Abílio A M. de Moura, Carlos E. Aun, Giulio Gavini, Igor Prokopowitsch, José L. Lage Marques, Manuel E. de L. Machado e Marcelo dos Santos, a minha sincera gratidão.

Aos professores Marilza Massafelli, Jaime Carlik, Maurício Nunes, Sergio de Oliveira e Neivaldo J. A de Souza, pela oportunidade de conviver, pelo incentivo, pela enorme paciência e principalmente pela confiança e amizade. 
As minhas amigas: Rosa M Farias, Paula Quarterolo, Eliane Dalben, Sandra Lopes e Lúcia Portes, pelo entusiasmo e sincero incentivo.

Aos meus amigos e companheiros de Pós-Graduação: Bruno Cavalcanti, Cid Manicardi, José Lauriere, Maria Renata, Christa Feller, Kali Amaral, Mara Felippe, Lorena Ribeiro, Stella Katayama, Patrícia Guinle, Cristiane Exposito e Leonardo Gonçalves, pelo espírito de humanidade com que nos tratamos diariamente.

Aos funcionários do Departamento de Dentística : Ana Maria, Neuza, Kátia, Arnaldo, Luizinho, Aldo e David.

Por fim, mas não menos importantes, aos meus amigos de todas as horas, pelo seu apoio, por todos os conselhos e principalmente pelo carinho e compreensão, em todos os momentos dessa jornada: Vera C., Pedro, Sérgio Trevelin, Nei, Victor, Elisa, Luiz, Ary e Zé Luiz, que tanto contribuíram para a concretização deste ideal.

A todos, minha eterna gratidão 
Correia VFP. Avaliação in vitro da citotoxicidade do alendronato de sódio sobre fibroblastos de ligamento periodontal de humanos em cultura celular [Dissertação de Mestrado]. São Paulo: Faculdade de Odontologia da USP; 2005.

\section{RESUMO}

Os processos de reabsorção radicular externa, geralmente, estão associados aos traumatismos dentários que atingem os tecidos de sustentação e suporte, principalmente a avulsão e a intrusão. A terapia endodôntica nesses casos, deve visar a estabilização ou paralisação deste processo através da utilização de medicação intracanal que possa inibir a atividade osteoclástica, como os bisfosfonatos desde que, esse fármaco seja biocompatível. Neste sentido, o objetivo desse estudo foi analisar a citotoxicidade do alendronato de sódio sobre fibroblastos do ligamento periodontal humano em cultura celular. As células foram cultivadas na densidade de $1 \times 10^{3}$ células/placa. Os grupos experimentais foram: G1 (controle) sem alendronato de sódio e G2, G3 e G4 com o alendronato nas concentrações de $10^{-5}, 10^{-6}$ e $10^{-7} \mathrm{M}$ respectivamente. Nos tempos experimentais de 1, 6, 12 e 24 horas (curto prazo) foi analisada a viabilidade celular e em 2, 4, 6 e 8 dias (longo prazo) a sobrevivência celular. Os resultados em triplicata foram analisados estatisticamente e mostraram que as culturas tratadas com a maior concentração da droga (G2), apresentaram porcentagens de viabilidade celular significantemente menores $(p<0.01)$, que as dos outros grupos (G1, G3 e G4) nos tempos de 12 e 24 horas. $\mathrm{O}$ 
crescimento celular nos grupos G2 e G3 foram similares. O G2 apresentou crescimento, significantemente menor que dos demais grupos $(p<0.05)$. Concluiu-se que o alendronato de sódio, em contato direto com fibroblastos de ligamento periodontal humano em cultura, é citotóxico em concentrações mais elevadas $\left(10^{-5}\right.$ e $\left.10^{-6} \mathrm{M}\right)$.

Palavras-Chave: Reabsorção Radicular; Bisfosfonatos; Alendronato de sódio; Cultura celular; Medicação intra-canal 
Correia VFP. In vitro citotoxicity evaluation of sodium ale ndronate on cultured human periodontal ligament fibroblasts [Dissertação de Mestrado]. São Paulo: School of Dentistry, University of São Paulo; 2005.

\section{ABSTRACT}

The external root resorption processes are usually associated with dental trauma, mainly avulsion and intrusion. In such cases, the endodontic therapy aims the process stabilization and paralysation, through utilization of medications that can inhibit the osteoclastic activity, like bisphosphonates, since this drug would be biocompatible. The aim of this study was to analyze the sodium alendronate citotoxicity on human periodontal ligament fibroblasts. Cells were plated in a density of $1 \times 10^{3}$ cells/dish. The experimental groups were: GI (control) no sodium alendronate, and GII, GIII and GIV with sodium alendronate at the concentrations of $10^{-5}, 10^{-6}$ and $10^{-7} \mathrm{M}$, respectively. The experiment times were 1, 6, 12 and 24 hours (short term) for viability and 2, 4, 6 and 8 days (long term) for cell survival. Data in triplicate were statistically analyzed. Cultures treated with the highest alendronate concentration (GII) showed cell viability percentages significantly lower $(p<0.01)$ than those of the other groups (GI, GIII and GIV), at 12 and 24 hours. Cell growth on GII and GIII groups was similar. Gll presented smaller growth than the other groups $(p<0.05)$. We concluded that sodium alendronate, on direct contact with human periodontal ligament fibroblasts, is citotoxic in concentrations higher than of $10^{-6} \mathrm{M}$.

Keywords: Root Resorption; Bisphosphonates; Sodium Alendronate; Cell Culture; Intracanal Medication 


\section{LISTA DE ILUSTRAÇÕES}

p.

Figura 4.1 - Representação esquemática de sub-cultivo, para a realização dos testes de curto e longo prazos.

Figura 4.2-Representação do processo de contagem celular. .72

Figura 4.3 - Fotografia das placas de Petri, dentro da capela de fluxo laminar. .75

Figura 5.1 - Fotografia das culturas de fibroblasto FL3 no período de 6 dias de contato com as concentrações de ALN. 79

Figura 5.2 - Fotografia das culturas de fibroblasto FL3 no período de 8 dias de contato com as concentrações de ALN. .80

Gráfico 5.1 - Desvios padrão e médias $( \pm 1)$ dos percentuais de células sobreviventes -curto prazo. .81

Gráfico 5.2 - Desvios padrão e médias $( \pm 1)$ dos percentuais de células sobreviventes $\left(10^{3}\right)$-longo prazo 


\section{LISTA DE TABELAS}

Tabela 5.1 - Médias e desvios padrão para o percentual

de células sobreviventes - curto prazo

Tabela 5.2 - Análise de variância para percentual - curto prazo.

82

Tabela 5.3 - Níveis descritivos para comparações múltiplas

pelo método de Tukey - percentual - para curto prazo.

Tabela 5.4 - Médias e desvios padrão para a contagem de células sobreviventes $\left(10^{3}\right)$ - longo prazo .85

Tabela 5.5 - Análise de variância para percentual - longo.prazo. .86

Tabela 5.6 - Níveis descritivos para comparações múltiplas pelo método de Tukey - contagem - longo prazo. .87

APÊNDICE A - Valores originais da viabilidade celular (\%), distribuídos de acordo com os tempos experimentais - curto prazo. 109 
APÊNDICE B - Valores originais da viabilidade celular $\left(\mathrm{n} \times 10^{3}\right)$, distribuídos de acordo com os tempos experimentais - longo prazo. 110

APÊNDICE C - Níveis descritivos para comparações múltiplas pelo método de Tukey - curto prazo G I ao longo do tempo. 111

APÊNDICE D - Níveis descritivos para comparações múltiplas pelo método de Tukey - curto prazo G II ao longo do tempo.

APÊNDICE E - Níveis descritivos para comparações múltiplas pelo método de Tukey - curto prazo G III ao longo do tempo. 111

APÊNDICE F - Níveis descritivos para comparações múltiplas pelo método de Tukey - curto prazo G IV ao longo do tempo. 111

APÊNDICE G - Níveis descritivos para comparações múltiplas pelo método de Tukey - curto prazo grupos no momento $0 \mathrm{~h}$ 
APÊNDICE H - Níveis descritivos para comparações múltiplas pelo método de Tukey - curto prazo grupos no momento $6 \mathrm{~h}$ 112

APÊNDICE I - Níveis descritivos para comparações múltiplas pelo método de Tukey - curto prazo grupos no momento $12 \mathrm{~h}$ 112

APÊNDICE J - Níveis descritivos para comparações múltiplas pelo método de Tukey - curto prazo grupos no momento $24 \mathrm{~h}$. 112

APÊNDICE K - Níveis descritivos para comparações múltiplas pelo método de Tukey - longo prazo G I ao longo do tempo 113

APÊNDICE L - Níveis descritivos para comparações múltiplas pelo método de Tukey - longo prazo G II ao longo do tempo .113

APÊNDICE M - Níveis descritivos para comparações múltiplas pelo método de Tukey - longo prazoG III ao longo do tempo 
APÊNDICE N - Níveis descritivos para comparações múltiplas

pelo método de Tukey - longo prazo -

G IV ao longo do tempo

APÊNDICE O - Níveis descritivos para comparações múltiplas

pelo método de Tukey - longo prazo -

grupos no momento 2 dias.

114

APÊNDICE P - Níveis descritivos para comparações múltiplas

pelo método de Tukey - longo prazo -

grupos no momento 4 dias.

.114

APÊNDICE Q - Níveis descritivos para comparações múltiplas

pelo método de Tukey - longo prazo -

grupos no momento 6 dias.

114

APÊNDICE R - Níveis descritivos para comparações múltiplas

pelo método de Tukey - longo prazo -

grupos no momento 8 dias.

.114 


\section{LISTA DE ABREVIATURAS E SIGLAS}

$\begin{array}{ll}\text { ALN } & \text { Alendronato de sódio } \\ \text { CSFs } & \text { Fatores colono estimulantes } \\ \text { DMSO } & \text { Di-metil-sulfóxido } \\ \text { DMEM } & \text { Meio de cultura de Eagle modificado por Dulbecco } \\ \text { et al. } & \text { eti alii } \\ \text { HBSS } & \text { Solução salina balanceada de Hank } \\ \text { IL-1 } & \text { Interleucina 1 } \\ \text { LIF } & \text { Fator inibidor de leucemia } \\ \text { OAF } & \text { Fator de ativação de osteoclasto } \\ \text { PBS } & \text { Hormônio Paratireóideo } \\ \text { P-C-P } & \text { Folução tampão fosfato-salina sem cálcio e sem } \\ & \text { magnesio }\end{array}$


TGF- $B$

Fator de crescimento de transformação ß

TNFs

Fator de necrose tumoral 


\section{LISTA DE SÍMBOLOS}

\begin{tabular}{ll}
$\mathrm{Ca}^{++}$ & Íon Cálcio \\
$\mathrm{CO}_{2}$ & Gás carbônico \\
$\mathrm{cm}^{2}$ & centímetro quadrado \\
${ }^{0} \mathrm{C}$ & grau Celsius \\
$\mathrm{H}^{+}$ & Íon Hidrogênio \\
$\mathrm{g}$ & grama \\
$\mathrm{mg}$ & miligramas \\
$\mathrm{mg} / \mathrm{Kg}$ & miligramas por quilogramas \\
$\mathrm{mL}$ & mililitro \\
$\mathrm{mm}$ & milímetros \\
$\mathrm{mol} / \mathrm{L}$ & mol por litro \\
$\mathrm{M}$ & molar \\
$\mathrm{pH}$ & potencial hidrogeniônico \\
( & marca registrada \\
\hline
\end{tabular}




\section{SUMÁRIO}

1 INTRODUÇÃO

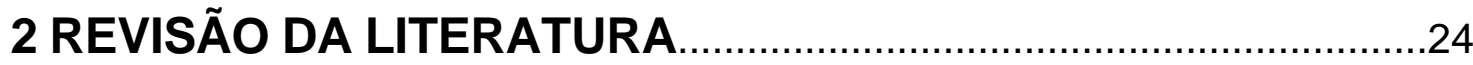

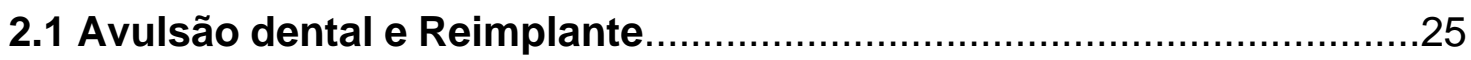

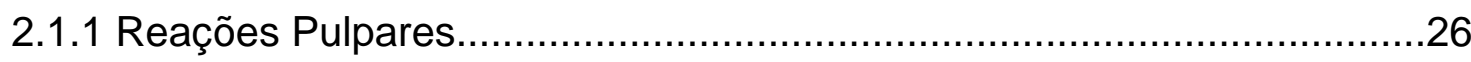

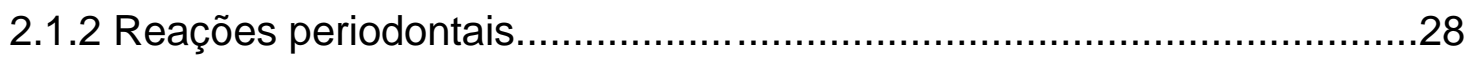

2.2 Meios de estocagem - períodos extra-alveolar .............................32

2.3 Tratamento endodôntico de dente avulsionado............................36

2.4 Tratamento das reabsorções................................................... 37

2.4.1 Mecanismo de reabsorção dos tecidos duros.................................38

2.5 medicação intracanal para traumatismo dentário ..........................43

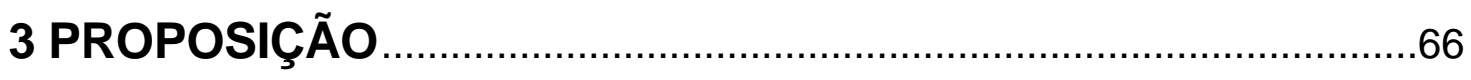

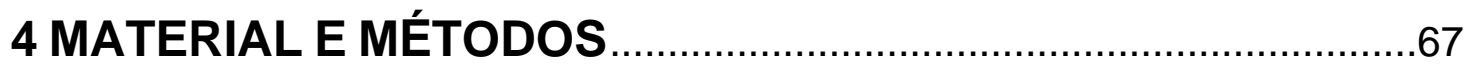

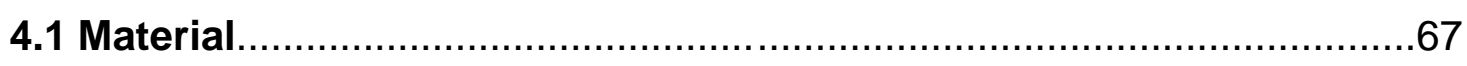

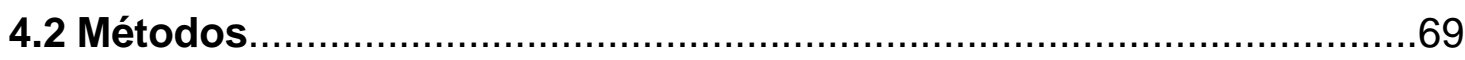

4.2.1 Cultivo celular e determinação do número de

células existentes no frasco original...........................................69

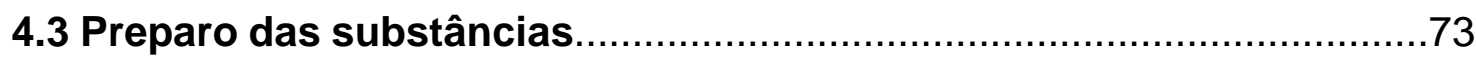

4.4 Teste de viabilidade celular (curto prazo) ...................................... 74

4.5 Teste de sobrevivência celular (longo prazo).............................76

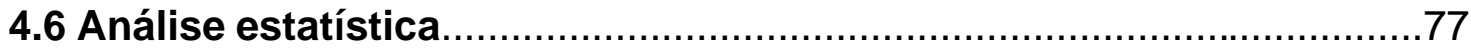




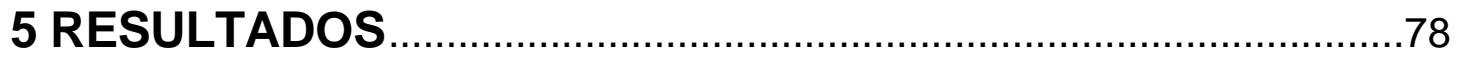

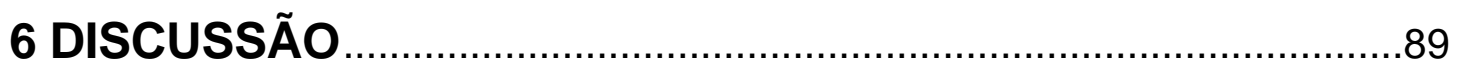

7CONCLUSÕES

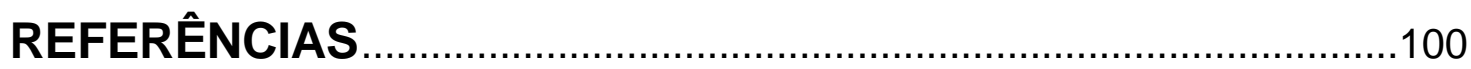

APÊNDICE

ANEXOS 


\section{INTRODUÇÃO}

Vários estudos epidemiológicos mostram uma elevada incidência do traumatismo dental, principalmente em crianças e adultos jovens. Essas ocorrências se devem ao fato, destes grupos estarem mais sujeitos a batidas, quedas e acidentes, muitas vezes causados pela prática de esportes ou até mesmo durante brincadeiras. No caso dos adultos, agressões físicas e acidentes automobilísticos se destacam como as principais causas do trauma dental.

Dentre os diversos tipos de traumatismo dental, o mais comum é a fratura coronária, cujo prognóstico é geralmente favorável, enquanto que a avulsão e a luxação intrusiva são os que apresentam as conseqüências mais severas, por se tratarem de injúrias complexas que afetam não só os tecidos duros e a polpa dental mas também os tecidos de sustentação. A avulsão dental ocorre com maior freqüência nos incisivos centrais superiores podendo também atingir os incisivos inferiores. Dentre as conseqüências temos as reabsorções externas principalmente a do tipo inflamatória substitutiva ou anquilose.

A resposta inflamatória, visando eliminar os tecidos danificados, desencadeia um processo de reabsorção que na presença de microorganismos nos túbulos dentinários promove reabsorção do tipo inflamatória que na ausência do ligamento periodontal, temos caracterizado uma reabsorção do tipo substitutiva, pois ocorre uma gradativa substituição 
do tecido dental por tecido ósseo, culminando com a perda do elemento dental afetado.

O tratamento para essa injúria está diretamente ligado à terapia endodôntica, principalmente à fase de medicação intracanal, onde se pretende paralisar ou estabilizar o processo de reabsorção, dando condições para que o dente permaneça o maior tempo na cavidade bucal. Buscando alternativas, vários fármacos foram estudados e utilizados com o objetivo de diminuir ou até mesmo inibir o processo de reabsorção, para prolongar o período de permanência do dente em função.

O hidróxido de cálcio tem sido empregado como medicação intracanal nos casos de reabsorções radiculares inflamatórias em função das suas propriedades antimicrobianas e neutralizadoras do $\mathrm{pH}$ ácido, mas, nos casos de reabsorções substitutivas, os resultados têm se mostrado insatisfatórios, o que nos leva à procura de outros medicamentos para esse fim.

É importante salientar que o tecido ósseo sofre um constante processo de remodelação, que se desenvolve mais rapidamente em indivíduos jovens, podendo ser retardado ou acelerado em decorrência de alguns processos patológicos. Essa remodelação pode ser afetada por várias drogas, entre as quais: a calcitonina e os bisfofonatos.

A calcitonina endógena é um hormônio polipepitídeo cuja principal ação é a de reguladora do metabolismo do cálcio, orientando o organismo na prevenção da reabsorção ou a excessiva neoformação óssea. Decorrente dessa ação, foi proposta a utilização da calcitonina sintética de salmão como medicação intracanal após o preparo químico cirúrgico em dentes 
reimplantados, visando a redução da atividade osteoclástica e a supressão do processo inflamatório, diminuindo assim, a velocidade de reabsorção radicular.

Os bisfosfonatos são substâncias análogas do pirofosfato, que reduzem o índice de dissolução da hidroxiapatita mineral do osso, agindo pela inibição da atividade dos osteoclastos, impedindo assim os processos de reabsorção óssea.

Desta forma, com a intenção de contribuir para o estudo sobre a efetividade de medicações utilizadas no tratamento de reabsorções radiculares externas via canal, como os bisfosfonatos, parece ser aceitável o desenvolvimento de um trabalho experimental em cultura de células, para avaliar sua citotoxicidade. 


\section{REVISÃO DA LITERATURA}

Dentre as injúrias traumáticas que afetam os tecidos de sustentação do órgão dental, a avulsão e a intrusão dental são as que apresentam os maiores danos às estruturas pulpares e periodontais, pois ocorre a ruptura do suprimento vásculo-nervoso da região periapical que por si, pode promover alterações degenerativas no tecido pulpar. Além disso, as injúrias ocorridas nos tecidos de sustentação do dente freqüentemente repercutem de forma negativa nas estruturas dentárias, podendo levar inclusive à perda precoce deste elemento. Fatores como estágio de desenvolvimento radicular, condição pulpar e periodontal, tipo e extensão da lesão, tempo ocorrido desde o trauma até o atendimento de urgência e a conduta do profissional irão repercutir decisivamente no prognóstico.

O traumatismo dental constitui uma ocorrência rotineira na prática da odontologia, uma vez que ocorre em maior freqüência em pacientes jovens, onde os processos de formação e maturação pulpar e periodontal ainda não foram concluídos.

Os pacientes traumatizados apresentam não somente lesões físicas, mas também comprometimento psicológico e emocional grave, já que na dependência da severidade do trauma, as seqüelas podem levar à perda do órgão dental (CAMARGO, 1998). Para Lage-Marques (1998), essa situação exige que todos os esforços terapêuticos sejam aplicados com a finalidade de se manter o elemento dental em condições de exercer suas funções, 
devendo o profissional estar apto para esclarecer as dúvidas e preocupações do paciente, buscando nele e nos responsáveis diretos uma ampla conscientização e colaboração. Ainda para o mesmo autor, é importante reconhecer o tipo de lesão traumática que 0 paciente foi acometido e identificar sua importância, pois, às vezes, danos de pouca expressão clínica podem causar seqüelas irreversíveis.

Na ocorrência da intrusão ou avulsão dental, o ligamento periodontal se rompe e os vasos e nervos da região apical são severamente comprometidos, aumentando a possibilidade de evolução para degeneração dos tecidos pulpar e periodontal. Deve-se considerar ainda a idade dental, pois o prognóstico varia muito quando se comparam dentes com ápices totalmente formados com dentes em estágio de formação radicular.

Alterações na vitalidade pulpar, processos de mortificação pulpar, calcificações difusas e reabsorções radiculares internas e externas, são freqüentemente as seqüelas relacionadas a dentes que sofreram algum tipo de lesão traumática, cuja gravidade está diretamente associada à intensidade e direção da incidência do trauma, bem como com a presença ou não de contaminação pulpar e periodontal.

\subsection{Avulsão dental e reimplante}

As reações patológicas de dentes reimplantados podem ser divididas em reações pulpares e periodontais. 


\subsubsection{Reações pulpares}

Quando um dente sofre um total deslocamento de seu alvéolo, os vasos do forame apical são injuriados e lacerados, provocando reações na polpa dental que dependem da severidade e duração dos distúrbios circulatórios, do estágio de formação radicular e da contaminação bacteriana nos tecidos afetados. Andreasen e Vestergaard-Pedersen (1985), concluíram que o risco de uma necrose pulpar aumenta com o evoluir dos estágios de formação radicular e com a severidade da luxação.

Andreasen e Andreasen (1994), afirmaram a partir de estudos clínicos e histológicos em seres humanos e animais, que a cicatrização pulpar necessita de um forame apical aberto e uma polpa relativamente íntegra. $\mathrm{O}$ tempo necessário para a formação de novos vasos, a reinervação e a presença ou não de infecção definem a reparação quando o canal radicular irá se obliterar devido a uma aceleração de deposição de dentina reparativa, mostrando claramente que existe uma relação direta entre o desenvolvimento radicular e a revascularização pulpar, sendo raro este fenômeno quando a mortificação está presente. Nestes casos as reabsorções, principalmente, as do tipo inflamatórias, são freqüentemente observadas.

Andreasen (1981), verificou o efeito do meio de conservação e o período extra-alveolar na cicatrização periodontal após o reimplante em dentes de macacos, e pode concluir que a reabsorção inflamatória foi fato 
comum em dentes secos com longos períodos fora do alvéolo e que a reabsorção substitutiva mostrou uma forte relação com dentes secos e reimplantados após 60 minutos.

Schatz, Hausherr e Joho (1995), observaram a cicatrização periodontal através de exames clínicos e radiográficos em reimplantes de dentes avulsionados em períodos extra-alveolares de $1 \mathrm{~h}$ e $3 \mathrm{~h}$, e demonstraram que $83,3 \%$ dos processos de reabsorção inflamatória ocorreram nos reimplantes realizados após $3 \mathrm{~h}$.

Andreasen et al. (1995b), também concluíram que períodos extraalveolares prolongados, independentemente do tipo de material de estocagem, também colaboravam sensivelmente para a diminuição das chances de revascularização.

Como resultado do deslocamento total do dente, o suprimento vascular da interface pulpo-periodontal pode romper-se totalmente, levando a alterações degenerativas em todo o tecido pulpar. A polpa traumatizada, poderá induzir uma resposta inflamatória que desencadeia um processo de reabsorção radicular que, na presença de bactérias, é chamada reabsorção inflamatória, e na ausência do ligamento periodontal, é denominada reabsorção substitutiva (ANDREASEN et al., 1995b).

A reabsorção inflamatória radicular é uma complicação comum nos casos de reimplante em dentes avulsionados, ocorrendo com freqüência quando esses são mantidos por um longo período extra-alveolar ou conservados inadequadamente antes do reimplante (ANDREASEN, 1981a) . 
Para Melo (1998), caracteriza-se uma reabsorção inflamatória quando a pré-dentina ou o pré-cemento são mecanicamente agredidos ou removidos, e nessa área, ocorre uma colonização de osteoclastos que darão início ao processo. As células de reabsorção necessitam de um estímulo contínuo, que pode ser mantido através de uma irritação mecânica no tecido e/ou infecção do canal radicular, podendo tornar o processo de reabsorção progressivo, levando à destruição radicular. Nestes casos, bem como o subseqüente reposicionamento ou procedimentos de reimplante, podem provocar inevitáveis danos à raiz, resultando em áreas sem cemento na superfície radicular tornando-a quimiotática para fagocitose, dando início a uma reabsorção transitória que, induzida por essa área desnuda, pode expor a dentina tubular radicular. Os produtos bacterianos do canal radicular infectado podem então alcançar áreas de reabsorção na superfície radicular sustentando dessa forma, o processo reabsortivo.

\subsubsection{Reações periodontais}

Sempre que o tecido de sustentação é lesado, instala-se uma reação inflamatória que desencadeia o processo de reabsorção radicular.

A inflamação dos tecidos periodontais está presente na área de reabsorção do cemento e dentina. Esse infiltrado periodontal consiste de um tecido de granulação com linfócitos, células plasmáticas e leucócitos 
polimorfonucleares, já o osso alveolar é reabsorvido por células osteoclásticas multinucleadas no interior das lacunas de Howship. Reabsorção similar acontece na superfície radicular por ação de células clásticas que apresentam propriedades enzimáticas parecidas, como a presença da fosfatase ácida taratro-resistente, agindo de forma a produzir grandes cavidades e lacunas de reabsorção. Estas cavidades de reabsorção comunicam-se diretamente com a polpa por meio dos túbulos dentinários, que quando necrótica, seus produtos tóxicos e bacterianos atuam diretamente no ligamento periodontal provocando uma resposta inflamatória local, intensificando o processo de reabsorção já instalado. Tal processo pode evoluir rapidamente em dentes reimplantados de pacientes jovens por apresentarem paredes dentinárias delgadas e túbulos dentinários amplos. A primeira evidência radiográfica revela-se inicialmente no terço apical, após três semanas da injúria.

A anquilose representa a fusão do osso alveolar com a superfície radicular e pode ser determinada histologicamente em torno de duas semanas após o reimplante. Sua etiologia parece estar relacionada com a ausência de ligamento periodontal na superfície da raiz. Este tecido alterado é composto por células progenitores da medula óssea adjacente que, apresentando potencial osteogênico, desencadeiam a anquilose (LINE; POLSON; ZANDER, 1974). Quando assume uma forma transitória, observase seu desaparecimento após determinado período, ficando restrita a pequenas zonas lesionadas da superfície radicular. A forma denominada reabsorção progressiva, desenvolve-se em diferentes direções reabsorvendo 
gradualmente toda a raiz, caracterizada radiograficamente pelo desaparecimento do espaço do ligamento periodontal e substituição continuada raiz por uma matriz óssea.

A anquilose, segundo Andreasen et al. (1995b), é a mais freqüente complicação pós avulsão traumática relacionada ao ligamento periodontal e também, com maior dificuldade de diagnóstico, tornando-se um grave problema para o planejamento da terapia.

Andreasen e Hjorting-Hansen (1966), reportaram um estudo clínico e radiográfico de 110 dentes reimplantados observados num período de 2 meses a 13 anos. Três tipos de manifestações foram observados radiograficamente: cura com presença de espaço de ligamento periodontal normal, reabsorções substitutivas e reabsorções inflamatórias. O tempo decorrido entre a avulsão e o reimplante mostroutse diretamente relacionado com a reabsorção, ou seja, os dentes que foram reimplantados em até 30 minutos não apresentaram sinais de reabsorção.

Oikarien, Gundlach e Pfeifer (1987), avaliando complicações tardias em 172 dentes luxados e avulsionados, verificaram que as reabsorções radiculares externas foram encontradas em $19 \%$ dos casos e relacionadas com o tipo de tratamento imediato ao acidente. A obliteração do canal, parcial ou total foi encontrada em $24 \%$ dos casos e relacionoutse estatisticamente com o estágio de formação radicular e a idade do paciente. Concluíram também que os dentes reimplantados com ligamento periodontal necrótico, apresentaram uma alta incidência de reabsorções e anquilose. As mesmas observações foram feitas por Duggal, Toumba e Paterson (1994), 
onde descrevem evidências de reabsorções substitutivas em dentes que foram reimplantados tardiamente (10 dias após a avulsão), não apresentando qualquer possibilidade de vitalidade periodontal.

Andreasen (1981a), usando modelos experimentais em macacos, confirmou a pouca resistência do tecido periodontal a períodos extraalveolares a seco, pois esta situação permite a evaporação de água presente nestas células levando à sua mortificação. Achados esses, também confirmados por Söder et al. (1977).

Cabe lembrar que a anquilose dento-alveolar e a reabsorção substitutiva, muitas vezes tida como sinônimos, não são de origem pulpar, e ocorrem devido à necrose do ligamento periodontal. Para Lage-Marques (1998), o mecanismo da anquilose dento-alveolar ocorre em lesões mais extensas, onde o processo inflamatório tem inicialmente a função de remover os detritos resultantes do dano causado pelo trauma, e, onde, após essa função, as células disputam o preenchimento do espaço vazio na região periodontal. Freqüentemente, as células precursoras do tecido ósseo se movem para a região mais rapidamente que as células do tecido periodontal, ficando em contato direto com a superfície radicular, histologicamente verificada pela ausência de cemento e do ligamento periodontal. Radiograficamente não há distinção entre a raiz e o tecido ósseo e a lâmina dura e o espaço periodontal estão ausentes. 


\subsection{Meios de estocagem - período extra-alveolar}

O estudo realizado por Söder et al. (1977), verificou os efeitos nocivos no ligamento periodontal a seco antes do reimplante. Foram utilizados dentes humanos e de macacos que após extração, permaneceram a seco por períodos de 0, 30, 60, 90 e 120 minutos antes de serem acondicionados no meio de cultura. Os autores observaram que a quantidade de células declina rapidamente com o aumento do período de secagem e que após 2 horas não foi possível demonstrar viabilidade celular.

Blömlof, Lindskog e Hammarström (1981) trabalhando in vivo puderam avaliar a reparação do ligamento periodontal de dentes reimplantados de macacos, após armazenamento em leite ou saliva, por períodos de 1, 2, e 3 horas. Os resultados demonstraram menor presença de reabsorção inflamatória para os dentes armazenados no leite e que o armazenamento no leite por um tempo de 3 horas antes do reimplante, mostrou resultados semelhantes ao reimplante imediato.

Tancredo (1987), verificou que, quando o dente era transportado a seco, a possibilidade de ocorrer um processo reabsortivo era de $85 \%$, e inclusive, quando o período decorrido entre a avulsão e o reimplante fosse superior a noventa minutos.

A água corrente não é adequada para o armazenamento de um dente avulsionado, segundo Paiva e Antoniazzi (1988), pois a hipotonicidade resulta em lise das células do ligamento periodontal, potencializando a 
reabsorção. Ainda segundo esses autores, o leite a $40{ }^{\circ} \mathrm{C}$ forneceu boa viabilidade de células, pois esse meio é isotônico, livre de bactérias, com osmolaridade satisfatória $(250 \mathrm{mOsm} / \mathrm{Kg})$ e pH $(6.5$ - 6.8), além de fornecer nutrientes essenciais as células do ligamento periodontal.

Para Andreasen e Andreasen (1991), é fundamental que o meio de estocagem seja isotônico, livre de bactérias e possua correta osmolaridade e $\mathrm{pH}$, além do cuidado fundamental com o dente, não tocando ou raspando o ligamento.

A Associação Americana de Endodontia (TROPE, 1995), recomenda que quando da impossibilidade do reimplante imediato, deve-se manter o dente avulsionado em diferentes meios de transporte como soluções de HBSS, leite ou saliva até que possa ser reimplantado. Huang, Remeikis e Daniel (1996), trabalhando com cultura celular do ligamento periodontal, confirmaram a seqüência de soluções citadas acima, e afirmaram que o leite propicia boa viabilidade celular á curto prazo, mas, que a melhor solução foi a HBSS (Solução Salina Balanceada de Hank). Para esses mesmos autores, um bom meio não deve apenas ser capaz de conservar a viabilidade do ligamento periodontal, mas também estar disponível perto do local do acidente.

Shulman, Gedalia e Feingold (1973), realizaram um experimento em macacos, e concluíram que a imersão do dente avulsionado em uma solução de fluoreto de sódio fosfato acidulado $2 \%$, com pH 5.5 por 20 minutos antes do reimplante, aumenta a resistência do dente frente à reabsorção, graças à capacidade das soluções fluoretadas em converter 
hidroxiapatita em fluorapatita, resultando em cristais maiores que dão ao cemento uma maior resistência à dissolução.

Lindskog et al. (1985), estudaram os efeitos da remoção química do ligamento periodontal antes do reimplante e puderam observar que tal procedimento aumenta a resistência do cemento à reabsorção. Isso é explicado pela ausência de remanescentes necróticos da membrana periodontal que atuariam como estimuladores do processo reabsortivo. Os autores sugerem que para os casos de extenso dano às fibras do ligamento periodontal, essas devem ser removidas antes do reimplante.

Recentemente foi proposto para a prevenção e controle da anquilose e reabsorção substitutiva, o uso de um derivado da matriz de esmalte (EMDOGAIN®), para os casos de reimplante. Esse complexo protéico, segundo Hammarström (1997), facilita o crescimento de cementoblastos na superfície desnuda da raiz pelo aumento da migração e diferenciação de células progenitoras.

Filippi, Pohl e Von Arx (2002), avaliaram a eficiência do EMDOGAIN $\circledast$, no tratamento de dentes humanos traumatizados e com presença de anquilose em estágios iniciais ou presentes em áreas circunscritas, e observaram resultados favoráveis quanto à prevenção ou atraso da anquilose nos casos de traumatismos leves ou moderados, mas para os casos onde houve severos danos às fibras do ligamento, a recorrência da anquilose foi observada.

Uma série de fatores deve ser considerada na prevenção dos processos reabsortivos, como, por exemplo, a utilização de medicação 
sistêmica para dentes avulsionados e reimplantados, com o intuito de prevenir a contaminação bacteriana associada aos estímulos gerados pela reabsorção inflamatória (ANDREASEN; ANDREASEN, 2001). Essa recomendação foi fundamentada no trabalho de Hammarström et al. (1986), que avaliaram os efeitos da administração local e sistêmica de um antibiótico, na reparação periodontal de dentes de macacos reimplantados, e observaram que o tratamento sistêmico iniciado no momento do reimplante e administrado por mais 6 dias, foi capaz de prevenir a reabsorção inflamatória, enquanto que, quando a administração do antibiótico foi iniciada 3 semanas após o reimplante, não houve redução do processo reabsortivo.

Quanto às manobras locais, a utilização de contenções é usualmente recomendada para os casos de avulsão e reimplante. Segundo Barret e Kenny (1997), a contenção promove estabilização para o dente reimplantado no período inicial de reparação dos tecidos periodontais, porém deve permitir uma pequena movimentação, uma vez que, uma contenção rígida pode favorecer uma anquilose.

Já, para Andreasen e Andreasen (2001), a contenção normalmente é suficiente por uma semana, pois as fibras periodontais já estão reparadas neste intervalo. $O$ mesmo autor recomenda uma contenção rígida por 6 semanas, para os casos onde inexiste ligamento periodontal viável, pois esta é a única modalidade de reparo esperada nestas condições. 


\subsection{Tratamento endodôntico do dente avulsionado}

O tratamento do dente avulsionado é direcionado para prevenir ou minimizar os efeitos da mortificação pulpar e lesões nas fibras do ligamento periodontal, mantendo o órgão dental, o maior tempo possível na sua função. Com relação à necessidade e momento para a intervenção endodôntica nos dentes reimplantados, Flores et al. (2001) e Levin et al. (2001), afirmaram que para os casos de dentes com rizogênese incompleta e período extra-oral inferior à uma hora, deve-se esperar pela possibilidade de revascularização, onde um criterioso acompanhamento clínico e radiográfico deve ser executado e detectando-se sinais de necrose e a terapia endodôntica deverá ser realizada, o mais rápido possível.

Os efeitos da terapia endodôntica realizada antes do reimplante foi estudada in vivo por Andreasen (1981b), que constatou que tal procedimento aumentava a incidência de reabsorções substitutivas, indicando que tanto o procedimento de obturação como o material, poderiam agredir o ligamento periodontal na região apical aumentando a incidência da reabsorção substitutiva. Concluiu ainda que a terapia endodôntica deveria ser postergada, enquanto que o reimplante deve ser imediato.

Ainda para os dentes com rizogênese incompleta, que ficaram fora do alvéolo por um período superior a duas horas, os mesmos devem receber o mesmo tratamento destinado aos com formação radicular completada. 0 canal radicular só poderá ser obturado com guta-percha após a 
evidenciação radiográfica da completa formação radicular (GUEDES-PINTO; ISSAO, 1993).

Para os casos de rizogênese completa com perío dos extra-orais a seco inferiores há 1 hora, recomenda-se o início da terapia endodôntica após 7 a 10 dias do reimplante, pois nesse período, mesmo com a presença de necrose pulpar, o processo infeccioso pode estar ausente ou na sua fase inicial (LEVIN et al., 2001; ANDREASEN; ANDREASEN, 2001).

Caldeira et al. (2004), no Manual de Trauma do CADE da FOUSP, preconiza no seu guia para tratamento de dentes permanentes avulsionados com rizogênese completa e com período extra-alveolar superior a uma hora, que a terapia endodôntica pode ser realizada antes do reimplante, mas que a fase de obturação do canal, poderá ser realizada somente após a remoção da contenção (45 a 120 dias).

\subsection{Tratamento das reabsorções}

Os danos causados às estruturas periodontais e a polpa pelos traumatismos podem resultar em 3 diferentes tipos de reabsorção da superfície radicular: superficial, inflamatória e por substituição.

A reabsorção superficial não necessita de tratamento, pois é um processo de reparação que ocorre após injúrias de baixa intensidade nas estruturas periodontais. A presença de reabsorções inflamatórias implica na 
necessidade da terapia endodôntica com medicação intracanal, pois a reabsorção é estimulada pela presença de restos necróticos e contaminação bacteriana nos túbulos dentinários. Segundo Trope (1998), a reabsorção substitutiva proveniente de um traumatismo dental, pode ser considerada um processo fisiológico, pois não existe alternativa para a reversão deste processo.

Para que possíveis estratégias de tratamento das reabsorções sejam instaladas, se faz necessário compreender o mecanismo de reabsorção dos tecidos duros.

2.4.1 Mecanismo de reabsorção dos tecidos duros

Acredita-se que o mecanismo de reabsorção dos tecidos duros dentais seja muito semelhante à reabsorção óssea, já que as células envolvidas no processo assemelham-se tanto na forma como em função.

Os osteoclastos são as principais células de reabsorção óssea que atuam nos mecanismos de reparação após um trauma nos tecidos duros, bem como no sistema de defesa estabilizado em resposta a uma infecção. Para Andreasen e Andreasen (1994), uma atividade osteoclástica marcante pode ser a explicação para os fenômenos radiográficos encontrados póstrauma dental. 
Os dentinoclástos são morfologicamente similares aos osteoclastos, mas não tem o tamanho e número de núcleos destes, talvez pela diferença no substrato de ambos, contudo, com a presença da fosfatase ácida taratroresistente, agem de forma semelhante produzindo lacunas de reabsorção na superfície do tecido duro (PIERCE; LINDSKOG, 1989).

Os osteoclastos se formam a partir de células mononucleares derivadas de precursores hematopoiéticos do baço e medula óssea, que chegam ao local da reabsorção pela circulação sanguínea, enquanto que os osteoblastos e osteócitos provem de células osteoprogenitoras do esqueleto. Em nível ultra-estrutural, os osteoclastos possuem abundantes mitocôndrias, polissomos livres, retículos endoplasmáticos rugosos, complexo de Golgi, grânulos densos e vacúolos perinucleares. A característica mais notável do osteoclasto é a presença de uma borda rugosa, que consiste em um sistema complexo de dobras na membrana celular que aumenta a área de superfície. Adjacente a essa borda, aparece uma área citoplasmática denominada zona clara que mantém um sistema de microfilamentos totalmente destituído de organelas celulares (ANDREASEN; ANDREASEN, 2001).

Nos tecidos duros após um trauma, a resposta inflamatória se instala desencadeando a liberação de citocinas e a promoção da reabsorção tecidual cuja função é de remover o tecido ósseo danificado antes da reparação. Para tal, as camadas de cementoblastos e dentinoblastos devem apresentar-se íntegras, caso contrário, as camadas subseqüentes de tecido duro serão reabsorvidas devido uma intensa atividade osteoclástica, resultado da liberação de fatores ativadores dos osteoclastos. 
Nas contaminações bacterianas, a reabsorção é um importante mecanismo na luta contra estes agentes, pois ocorre na tentativa de eliminar bactérias ou seus produtos do interior dos túbulos dentinários e canal radicular, enquanto ocorre concomitantemente a formação de um tecido de granulação na área de reabsorção óssea periapical para a defesa contra os microorganismos aí existentes (BARRET; KENNY, 1997).

O processo de reabsorção óssea é complexo e requer ações seqüencialmente reguladas de dissolução mineral ácida e degradação da matriz orgânica pela atividade enzimática, tanto colagenolítica como não colagenolítica. Os osteoclastos quando aderidos à superfície óssea, têm a capacidade de degradar tanto a porção mineral como a orgânica, por acidificação do meio, promovendo dessa forma a dissolução da porção mineral. A adicificação requer que os osteoclastos possuam um mecanismo para a geração e liberação de íons $\mathrm{H}^{+}$, papel esse provavelmente desempenhado pelo ácido carbônico catalisado pelo $\mathrm{CO}_{2}$ existente nas células osteoblásticas, fato descrito por Andreasen e Andreasen (2001).

Ainda para esses autores, após a dissolução ácida da porção mineral, a etapa seguinte requer a dissolução enzimática da matriz orgânica exposta. Várias enzimas foram localizadas no interior dos retículos endoplasmáticos, complexo de Golgi e vesículas e vacúolos próximos à borda rugosa. Acredita-se que a colagenase e catepsinas lisossômicas sejam as mais importantes enzimas que degradam a matriz óssea, uma vez que a matriz orgânica é composta principalmente por colágeno, mas não se deve 
esquecer que, para a solubilização da porção mineral dos tecidos duros, são necessárias múltiplas enzimas.

Os mecanismos responsáveis pela ativação e desativação dos osteoclastos parecem estar relacionados com aqueles que atuam nos osteoblastos, resultando em ação tanto na deposição quanto na reabsorção. Sabe-se que os osteoblastos liberam um fator solúvel que se comunica com o osteoclasto, estimulando sua atividade, contribuindo dessa forma no mecanismo regulador de deposição e reabsorção óssea.

De acordo com Andreasen e Andreasen (2001), vários hormônios sistêmicos agem diretamente sobre a reabsorção óssea:

Hormônio paratireóideo (PTH): sua ação é obtida através da sua ligação com receptores nos osteoblastos que comunicam o sinal hormonal ao osteoclasto, iniciando dessa forma o processo de reabsorção. O PTH também inibe de forma significante a síntese de matriz pelos osteoblastos.

Calcitonina: é o hormônio que atua diretamente sobre os osteoclastos, inibindo a sua atividade.

1,25-diidroxivitamina D3: exerce sua ação como estimulador da reabsorção óssea, apesar do seu efeito não ser direto sobre os osteoclastos. Estimula a formação dos osteoclastos a partir de células precursoras, sendo necessário à presença de estroma acessório ou odontoblastos.

Esteróides sexuais: o estradiol causa uma inibição dose-dependente na reabsorção óssea, devido a redução da síntese local de citocinas com as interleucinas ou ainda por estimular a secreção de fatores de crescimento ósseo (TGF-ß). Essas alterações provavelmente desempenham um papel 
importante na redução da massa óssea que acompanha os quadros de deficiência de estrogênio.

Fatores de liberação local como as prostaglandinas E, F, A e B, a prostacilina e o lipopolissacarídeo bacteriano têm sido mostrados como estimuladores de reabsorção óssea (CHAMBERS, 1985). Outros fatores como fator necrótico tumoral (TNF), fator colono estimulante (CSFs) e o fator de leucemia (LIF), também atuam no processo de estímulo á reabsorção.

A descoberta do chamado fator de ativação de osteoclastos (OAF) incitou um grande interesse nos fatores locais e citocinas que regulam a função dos osteoclastos. As citocinas atuam como mensageiros intercelulares e são derivadas de células mononucleares da medula óssea ou diretamente de células ósseas, podendo estar incorporadas a matriz óssea e serem liberadas de uma forma biologicamente ativa durante a reabsorção. A interleucina-1 (IL-1) é a mais potente das interleucinas que age diretamente na estimulação de reabsorção óssea, tendo sua ação mediada pelos odontoblastos.

As condições ambientais também podem afetar a atividade osteoclástica, pois uma acidose estimula a liberação de mineral do osso e a hipercalciúria, um $\mathrm{pH}$ baixo no meio também estimula diretamente a reabsorção mediada pelas células osteoblásticas. Para Andreasen e Andreasen (2001), tal informação é de suma importância, uma vez que tem implicação direta na inflamação, pois a reabsorção óssea pode ser aumentada numa doença inflamatória, simplesmente porque o local geralmente tem um $\mathrm{pH}$ reduzido. Ainda para o mesmo autor, um 
traumatismo mecânico ao periodonto ou aos tecidos circunvizinhos, levando ao surgimento contínuo de irritantes, antígenos ou produtos bacterianos tóxicos podem resultar em reações imunológicas que desencadearão a liberação de mediadores não específicos, ativando as vias de inflamação.

\subsection{Medicação intracanal para traumatismo dentário}

O tratamento das reabsorções radiculares está diretamente ligado à terapia endodôntica, principalmente na fase de prevenção e remoção do estímulo da inflamação, ou seja, na remoção das bactérias e de seus produtos no interior do canal e também na fase de medicação intracanal onde se pretende interromper ou estabilizar os processos de reabsorção.

Neste sentido, se faz necessária uma busca incessante de possíveis medicações utilizadas dentro do canal radicular que possam promover diminuição efetiva ou eliminação do processo reabsortivo, otimizando o prognóstico do dente traumatizado mesmo em condições pouco favoráveis.

O procedimento clínico utilizado nos casos de avulsão dental é o reimplante com o intuito de promover a cicatrização do periodonto, prevenindo assim a instalação do processo de reabsorção inflamatória, da anquilose e subseqüentemente a reabsorção substitutiva.

Vale ressaltar que a conduta profissional nestes casos é de fundamental importância para o sucesso da terapia, uma vez que o 
tratamento do dente avulsionado está direcionado a procedimentos que devem ser tomados no sentido de retardar ou impedir que o processo de reabsorção se instale, mantendo assim o dente o máximo de tempo possível em sua função. Confirmada a necessidade da intervenção endodôntica, deve-se realizar a limpeza e desinfecção do canal radicular visando um aumento da permeabilidade dentinária para que uma medicação intracanal, por difusão, penetre nos túbulos dentinários atingindo a totalidade do sistema endodôntico, acorde Paiva e Antoniazzi, 1993.

Em busca da cura ou da reparação dos processos de reabsorções mais severos, que ainda apresentam grande dificuldade no âmbito do trauma dental, tem-se observado na literatura a busca por alternativas para se tratar essa patologia.

Tendo conhecimento dos processos que desencadeiam e mantém a reabsorção, associados aos conhecimentos da terapia endodôntica, é possível determinar a conduta clínica mais adequada, usando medicações que possam atingir a área de reabsorção, na tentativa de bloquear este processo. Para Vanderas (1993), a medicação intracanal ideal, ainda não foi encontrada e várias opções têm sido utilizadas.

Para Lage-Marques, Salazar Silva e Prokopowitsch (1995), o sucesso da terapia endodôntica nos casos de reabsorção está na escolha da correta medicação intracanal, que deverá atuar no espaço perirradicular, diminuindo a possibilidade de crescimento bacteriano e controlando o processo reabsortivo. Desde que promovida a sanificação e o aumento da permeabilidade dentinária, torna-se essencial à ação da medicação 
intracanal nos tecidos adjacentes para o tratamento das reabsorções radiculares, pois a mesma deve atingir à superfície externa radicular por simples difusão.

Sabe-se que a melhor condição para favorecer a reabsorção dos tecidos duros é o $\mathrm{pH}$ ácido. O princípio do uso do hidróxido de cálcio na reabsorção inflamatória baseia-se no fato de que os produtos ácidos, provenientes dos osteoclastos podem ser neutralizados, ajudando a prevenir a dissolução do componente mineral. Segundo Hammarström et al. (1986), a elevada alcalinidade do hidróxido de cálcio induziria a formação de um tecido mineralizado pela estimulação de enzimas (fosfatase alcalina e adenosina trifosfatase cálcio-dependente) e inibição da fosfatase ácida osteoclástica. Corroborando essa afirmação, Vaes (1988), afirmou que um $\mathrm{pH}$ alcalino pode ativar as fosfatases alcalinas que participam ativamente na formação de tecidos duros.

Foster, Kulild e Weller (1993), demonstraram que íons $\mathrm{H}^{+}$e $\mathrm{Ca}^{++}$, obtidos pela dissociação do Hidróxido de Cálcio utilizado como medicação intracanal, sofrem difusão pela dentina até a superfície externa radicular. Convém salientar que a difusão da medicação intracanal, particularmente naquelas á base de hidróxido de cálcio, permite que na superfície radicular externa ocorra mudança de $\mathrm{pH}$ suficiente para que, em alguns casos ocorresse a interrupção ou diminuição do processo reabsortivo.

Trope et al. (1992), avaliando em cães os efeitos do tratamento de curta (1 semana) e longa (8 semanas) duração com hidróxido de cálcio em dentes reimplantados previamente contaminados, concluíram que os 
modelos de reparação eram semelhantes quando o tratamento foi iniciado 14 dias após o reimplante. Em 1995, os mesmos autores, realizaram um experimento semelhante onde o uso de hidróxido de cálcio era iniciado quando sinais radiográficos de reabsorção eram detectados ou após um período de 4 semanas. Sob essas condições, a utilização prolongada do hidróxido de cálcio pareceu ser mais efetiva no tratamento de reabsorções inflamatórias já estabelecidas e que frente uma infecção de longa duração, o hidróxido de cálcio necessita de períodos maiores para exercer sua ação nos túbulos dentinários.

Andreasen (1981b) alertou para a possível ocorrência de anquilose em dentes reimplantados e tratados imediatamente com hidróxido de cálcio, pelo fato da medicação difundir-se pelo foramem apical, danificando os cementócitos, células essas importantes para o processo de reparação dos tecidos periodontais. No entanto, caso a medicação seja feita após duas semanas do reimplante, o dano parece não ocorrer. Concordando com esses achados, Konnis (1995), também indica o uso da medicação a base de hidróxido de cálcio após um período de duas semanas do reimplante, pois dessa maneira se evitaria o efeito citotóxico no ligamento periodontal durante a reparação e maturação das fibras colágenas.

Soares, Felippe e Lucena (1996), afirmaram que o hidróxido de cálcio pode necrosar as células nas lacunas de reabsorção, ou pelo menos, neutralizar o ácido láctico dos macrófagos e células clásticas, prevenindo dessa forma a dissolução do componente mineral da raiz. Além disso, um $\mathrm{pH}$ alcalino nos locais de reabsorção seria desfavorável à atividade da 
colagenase e hidrolase ácida das células de reabsorção, podendo estimular as fosfatases alcalinas, que parecem desempenhar um papel importante na formação de tecido duro e reparador.

A associação de antibióticos e corticosteróides têm sido utilizada na terapia endodôntica convencional graças a manutenção da sanificação obtida após o preparo químico cirúrgico e a moderação da resposta inflamatória inicial, mantendo-a em níveis moderados compatíveis com os padrões biológicos normais de reparação tecidual (BOMBANA, 1974).

Pierce e Lindskog (1987), verificaram in vivo, a capacidade de eliminação da reabsorção inflamatória com o uso da pasta Ledermix® , uma pasta composta por antibiótico e corticosteróide, que foi usada como medicação intracanal e que foi capaz de eliminar a reabsorção inflamatória. Os autores usaram incisivos de macacos que foram avulsionados e contaminados com placa bacteriana após acesso e remoção do tecido pulpar, e mantidos a seco 1 hora antes do reimplante. Após 3 semanas um grupo de dentes foi tratado endodonticamente e foi aplicado como medicação intracanal a pasta Ledermix®; o outro grupo permaneceu sem tratamento, servindo de controle. Ao final de 8 semanas os espécimes foram preparados para avaliação histológica. Os resultados demonstraram que a pasta além de eliminar a reabsorção inflamatória, também não lesou a membrana periodontal. Os autores relataram que apesar do controle da reabsorção inflamatória, havia um predomínio da reabsorção substitutiva.

Mais tarde, em 1989 os mesmos autores, demonstraram em culturas puras de dentinoclastos o efeito inibitório da pasta Ledermix® sobre estas 
células. Sob a microscopia de varredura puderam comprovar a separação e inativação das células que sofreram a ação da medicação quando comparada ao grupo controle.

Para Pierce (1989), o reimplante imediato em dentes com rizogênese completa, associado a uma terapia endodôntica precoce e a utilização da pasta Ledermix $\circledast$, parece oferecer uma excelente capacidade preventiva quanto ao aparecimento das reabsorções inflamatórias.

Pela grande dificuldade em se promover a reparação ou cura nos processos de reabsorção mais severos e pela limitada ação das medicações intracanal utilizadas, tem-se buscado na literatura outras alternativas, no sentido de reverter esta patologia.

Algumas drogas empregadas na área médica, principalmente no combate da osteoporose, poderiam ser alternativas interessantes no combate dos processos reabsortivos.

A osteoporose aparece como a doença de metabolismo ósseo mais comum nos países desenvolvidos, e seu aumento de incidência é tido como um importante problema de saúde pública (PATEL, 1996). Ele cita ainda algumas drogas (hormônios, esteróides anabolizantes, bisfosfonatos, vitamina $D$ e seus análogos e a calcitonina), que são utilizadas no tratamento dessa doença, agindo como supressores do processo de reabsorção óssea.

A calcitonina é um hormônio secretado pelas células parafoliculares da glândula tireóide ou células $C$ da tireóide humana que, em doses 
farmacológicas, promove a inibição da atividade osteoclástica, levando à queda dos níveis de cálcio plasmático.

A ação farmacológica da calcitonina pode ser resumida pela inibição da reabsorção óssea atuando na redução da atividade, mobilidade (desaparecimento da borda rugosa e da zona clara) e número de osteoclastos, retardando a desmineralização óssea. Por outro lado, pela depressão da atividade osteoclástica a calcitonina pode indiretamente atuar na atividade osteoblástica (AZRIA, 1989; CAMARGO, 1998) e a principal função desse hormônio é regular o metabolismo mineral especialmente o do cálcio, ajudando o organismo a lidar com a falta ou excesso deste no plasma sanguíneo. Em várias situações como crescimento, lactação, gravidez, etc, a calcitonina exerce um efeito inibitório direto no osteoclasto, sobre a sua atividade e número, diminuindo assim a reabsorção fisiológica do esqueleto humano. Essas células com alta capacidade de motilidade movem-se ao longo da superfície óssea promovendo a reabsorção do tecido, resultando em escavações denominadas de lacunas de Howship.

Pierce, Berg e Lindskog (1988), avaliaram em macacos, os efeitos da aplicação intracanal da calcitonina no controle de reabsorções inflamatórias em dentes reimplantados com contaminação do canal radicular e com ligamento periodontal necrótico. Os autores verificaram que a calcitonina foi eficiente no tratamento das reabsorções inflamatórias instaladas.

Prokopowitsch et al. (1990), estudaram em cães a ação da calcitonina quando utilizada como meio de armazenamento de dentes avulsionados antes do reimplante. Os autores verificaram que os dentes mantidos na 
calcitonina apresentaram menores índices de reabsorção quando comparados aos dentes mantidos a seco, em solução fisiológica ou leite por 1 hora antes do reimplante.

Em um artigo escrito por Lage-Marques, Salazar e Prokopowitsch (1995), os autores relataram uma conduta clínica frente ao trauma dental para os casos de avulsão, usando a calcitonina sintética de salmão imediatamente após o preparo químico-cirúrgico por dez minutos e posterior colocação de hidróxido de cálcio veiculado nesta medicação. Eles observaram que a calcitonina foi capaz de diminuir significativamente 0 processo de reabsorção radicular externa.

A afinidade e difusão da calcitonina nos tecidos duros do dente foram estudadas por Wiebkin et al. (1996), onde utilizaram um marcador radioativo para verificar a liberação da calcitonina através da raiz. Nos dentes com o cemento intacto foi necessário um período de 4 a 5 horas para que a calcitonina fosse detectada, porém uma liberação lenta foi observada durante um período de 9 dias. Para os dentes onde parte do cemento fora removido, a detecção foi mais rápida (2 horas) e foi observado, uma quantidade maior do medicamento durante o período de 9 dias.

Camargo (1998), também avaliou a difusão da calcitonina na dentina radicular valendo-se de um teste imunoenzimático e seus resultados comprovaram a capacidade da calcitonina atingir a superfície externa radicular, quando utilizada como medicação intracanal.

Anteriormente, Prokopowitsch e Andrade (1997), avaliaram qualitativamente, em um período de dois anos, 69 dentes reimplantados e 
tratados com calcitonina sintética de salmão imediatamente após o preparo químico cirúrgico como medicação intracanal por dez minutos e verificaram que $72,45 \%$ dos casos apresentavam prognóstico favorável.

$\mathrm{Na}$ busca de uma outra opção para o tratamento da osteoporose deparamo-nos com os bisfosfonatos, que de, acordo com Sato et al. (1991), são substâncias análogas sintéticas não hidrolisáveis do pirofosfato, onde o átomo central, o oxigênio, foi trocado pelo átomo de carbono, possibilitando assim uma nova droga que reduz o índice de dissolução da hidroxiapatita mineral do osso, impedindo dessa forma, os processos de reabsorção óssea.

Os bisfosfonatos agem por meio da inibição da atividade de reabsorção dos osteoclastos, daí serem empregados como agentes terapêuticos em doenças ósseas hiper reabsortivas como a doença de Paget, hipercalcemia maligna ou ainda na osteoporose, mas o seu mecanismo de ação ainda não está bem esclarecido (GEDDES et al.,1994).

Para Geddes et al. (1994), os bisfosfonatos caracterizam-se por dois grupos de fosfonatos ligados a um átomo de carbono geminal único $(P-C$ P), que possui duas cadeias laterais com estruturas variáveis $R 1$ e R2. A cadeia lateral R1 é a principal determinante de afinidade pelo mineral ósseo, com um grupo hidroxila aumentando a afinidade que difere ligeiramente de um bisfosfonato para outro. A cadeia lateral R2 determina a potência de antireabsorção, com os grupos amino ou piridinil, contendo nitrogênio.

Todos os bisfosfonatos aderem a hidroxiapatita em virtude de sua estrutura P - C - P, o que justifica sua rápida localização no tecido ósseo e 
sua seletiva ação no esqueleto. Após administração, os bisfosfonatos são rapidamente removidos da corrente sanguínea e eliminados pela urina ou absorvidos pelo esqueleto nas áreas de maior atividade celular óssea. Quando absorvido, o bisfosfonato liga-se a hidroxiapatita do osso exposto nos locais de reabsorção óssea, pois o osteoclasto gera um pH ácido que dissolve a matriz inorgânica liberando o bisfosfonato ligado a hidroxiapatita (PORRAS; HOLLAND; GERTZ, 1999).

Os exatos mecanismos celulares pelos quais os bisfosfonatos inibem a atividade dos osteoclastos ainda não são completamente compreendidos, mas as evidências sugerem que os bisfosfonatos inibem diretamente a reabsorção óssea por meio de alterações nas bordas onduladas dos osteoclastos e por meio do aumento de sua permeabilidade ao cálcio e a outros íons. A redução na reabsorção ajuda a restaurar o equilíbrio do cálcio e preservar o conteúdo mineral ósseo.

Com relação ao mecanismo de ação, acreditava-se inicialmente que a ligação dos bisfosfonatos com a hidroxiapatita resultava na diminuição da solubilidade, porém outros mecanismos também podem ocorrer como: a citotoxicidade ou injúria metabólica em osteoclastos maduros; inibição da ligação do osteoclasto ao osso; inibição de diferenciação e recrutamento ou ainda interferência nas propriedades estruturais dos osteoclastos são necessários para a reabsorção óssea (SATO et al., 1991).

Os mesmos autores realizaram um estudo em ratos usando um bisfosfonato radioativo e verificaram sua localização no tecido ósseo e seus efeitos na ultraestrutura dos osteoclastos. Esses autores demonstraram um 
mecanismo de atuação que tem seu início com a liberação do bisfosfonato ligado a hidroxiapatita, motivado pela acidificação produzida no inicio do processo de reabsorção e que essa droga deve atingir uma concentração entre 0.1 e $1 \mathrm{mM}$ na região da zona clara para aumentar a permeabilidade iônica da borda rugosa dos osteoclastos, dessa forma, a reabsorção cessa e as células perdem a borda rugosa.

Receptores especializados localizados na membrana dos osteoclastos reconhecem e se fixam em determinadas sequências peptídicas na matriz óssea, e uma vez fixados, a área é coberta por outra parte especializada da membrana da célula, conhecida como borda pregueada. É através dessa borda pregueada que os osteoclastos secretam íons $\mathrm{H}^{+}$e uma série de enzimas proteolíticas responsáveis pela reabsorção da matriz (FLEISCH, 1993).

Para Sahni et al. (1993), o efeito inibitório dos bisfosfonatos foi atribuído principalmente a uma injúria metabólica dos osteoclastos maduros quando eles ingerem os bisfosfonatos aderidos ao osso. Esse modo de ação foi suportado pelo fato de que os osteoclastos adquirem uma morfologia degenerativa que altera sua função na presença de um bisfosfonato. $O$ estudo realizado pelos autores, analisou o efeito de 5 diferentes bisfosfonatos, quanto à sua efetividade em culturas osteoclásticas. As soluções foram aplicadas em cavidades de reabsorção osteoclástica antes e após o isolamento com marfim e foram aplicadas co-culturas de uma linhagem celular de osteoblastos. Os resultados evidenciaram que parte da ação inibitória dos osteoclastos pelos bisfosfonatos foi mediada também pela 
ação nos osteoblastos. Os autores ainda relatam que achados conflitantes entre estudos in vivo e in vitro, sugerem que os bisfosfonatos não operam somente através de ações diretas na atividade osteoclástica ou recrutamento, mas também por outros mecanismos relacionados com a reabsorção óssea.

Segundo Fogelman (1996), a inibição da atividade osteoclástica poderia ser um efeito secundário de uma ação no osteoblasto, levando à produção de um inibidor de recrutamento e de sobrevivência de osteoclastos.

Nishikawa et al. (1996), verificaram a ação dos bisfosfonatos em células osteoblásticas e a inibição de formação de células osteoclásticas, e os seus achados sugeriram que o tratamento nas células osteoblásticas induziu ou aumentaram a atividade inibitória no meio condicionado na formação de células osteoclásticas e, além disso, foi evidenciado que pelo fato dos bisfosfonatos se depositarem preferencialmente na superfície óssea, quando liberados do tecido ósseo por difusão passiva ou durante a reabsorção, ocorre uma alta concentração no microambiente dos osteoblastos.

Em outra avaliação in vitro realizada por Garcia-Moreno et al. (1998), em cultura celular, demonstrou que $\mathrm{o}$ alendronato de sódio afeta a viabilidade dos osteoblastos humanos em concentrações maiores ou iguais a $10^{-4} \mathrm{~mol} / \mathrm{L}$, e que nenhuma célula viável foi observada nas culturas com concentrações maiores ou iguais a $10^{-3} \mathrm{~mol} / \mathrm{L}$. Concluiurse também, que 
nenhum efeito na capacidade de deposição mineral pelos osteoblastos foi observado em concentrações menores ou iguais a $10^{-5} \mathrm{~mol} / \mathrm{L}$.

A classificação das potências de anti-reabsorção dos bisfosfonatos segundo Geddes et al. (1994), mostra que em doses subcutâneas eficazes mais baixas, em $\mathrm{mg} / \mathrm{Kg}$ de peso corpóreo/dia, conforme determinado em modelo de rato, o alendronato de sódio tem uma potência de até 1000 vezes maior que o etidronato (um dos primeiros bisfosfonatos a ser utilizado clinicamente), para a inibição da reabsorção óssea e com uma segurança significativamente maior. Apesar de medidas em ratos, as potências relativas são relatadas na literatura como sendo muito similares em humanos.

Dentre os bisfosfonatos, o alendronato de sódio é um dos mais potentes aminobisfosfonatos. É um sal monosódico trihidratado, derivado do ácido alendrônico, caracterizado como um pó branco cristalino, solúvel em água e com pH de 4 a 5 (1\% de solução em água) (MARTINDALE,2002).

De acordo com Budavari et al. (1996), esta medicação é quimicamente descrita como: 4-amino-1-hidroxibutilideno-1, 1 bisfosfonato e com fórmula estrutural $\mathrm{C}_{4} \mathrm{H}_{13} \mathrm{NNaO}_{7} \mathrm{P}_{2} .3 \mathrm{H}_{2} \mathrm{O}$ de peso molecular $325,10 \mathrm{~g}$. Sua composição formada por quatro carbonos e com uma cadeia lateral do grupo amina inibe especificamente a reabsorção óssea causada pelos osteoclastos.

O alendronato de sódio depositado nas áreas de remodelação óssea quando não atua diretamente no osteoclasto, é incorporado na matriz do tecido ósseo neoformado ficando farmacologicamente inativo até o momento 
em que é exposto pelo processo de remodelação óssea (PORRAS; HOLLAND; GERTZ, 1999).

Estrutura química do alendronato de sódio

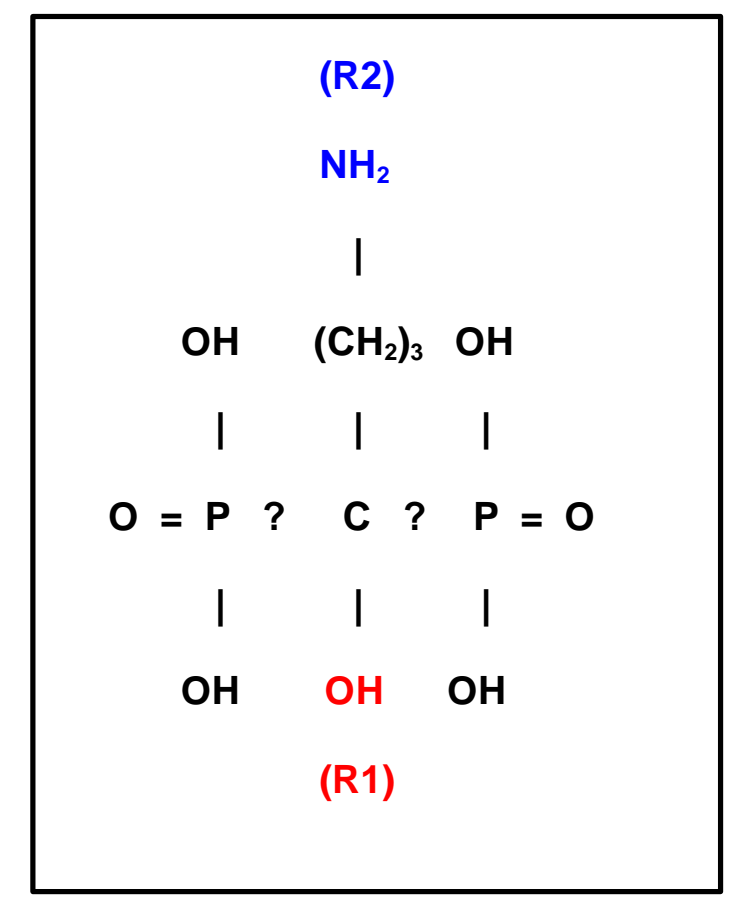

Pelo fato de ser incorporado ao osso, e sua liberação estar relacionada com o índice de remodelação óssea, o alendronato de sódio, assim como os outros bisfosfonatos, apresentam uma meia-vida extremamente longa. Segundo estudos de Kanis et al. (1995), a presença desse alendronato eliminado na urina, evidenciou uma meia-vida no tecido ósseo de aproximadamente 200 dias em ratos, mais de 3 anos em cães e mais de 10 anos em humanos.

Diversas pesquisas clínicas (ADAMI et al., 1994; HARRIS et al., 1993; LIBERMAN et al., 1995; SAAG et al., 1998), comprovaram a eficiência do 
alendronato de sódio para o tratamento de doenças do metabolismo ósseo e seu uso resultou em um aumento da densidade mineral óssea, que é fator determinante na diminuição da incidência de fraturas ósseas associadas a essas patologias.

Rodan (1998), sugere a presença de receptores para o bisfosfonato na membrana celular dos osteoclastos, que uma vez no seu interior, o bisfosfonato desencadeia uma série de alterações que levam à inibição da atividade de reabsorção óssea e apoptose destas células. Ainda para esse mesmo autor, existem 4 meios de inibição da atividade osteoclástica pelo alendronato: $\mathrm{Na}$ presença do alendronato de sódio, as células precursoras dos osteoclastos perdem a capacidade de proliferação, migração e diferenciação, impossibilitando a formação de novos osteoclastos. Ocorre também uma redução do número de osteoclastos ocasionando uma redução da reabsorção óssea. Inibição da atividade dos osteoclastos por via indireta, ou seja, os osteoblastos não são capazes de liberar determinados fatores que estimulam os osteoclastos. Inibição da atividade dos osteoclastos por via direta. $\mathrm{O}$ alendronato quando no interior dos osteoclastos, desencadeia algumas alterações como: perda da superfície com bordas irregulares da membrana celular e perda dos anéis de actina responsáveis pelo citoesqueleto, tornando os osteoclastos incapazes de reabsorver tecido ósseo. Apoptose dos osteoclastos pela redução de sua meia-vida e por conseqüência, redução do número de osteoclastos ativos.

Hernandez et al. (2001), através de uma análise teórica por simulação, comparou o aumento da densidade mineral óssea com a 
remodelação do tecido ósseo quando do uso do alendronato de sódio, com a finalidade de identificar dosagens mais adequadas para cada patologia óssea. Os autores concluíram que o aumento da densidade mineral óssea causado pelo alendronato foi atribuído à diminuição no turnover ósseo.

Uma outra pesquisa analisando comparativamente 0 efeito da calcitonina, do alendronato de sódio e do fluorfosfato em ratas ovarictomizadas realizado por Giavaresi et al. (2001), mostraram resultados indicativos que após o tratamento preventivo com alendronato, as propriedades estruturais e mecânicas do tecido ósseo femural são melhores que aquelas dos mesmos tecidos tratados com calcitonina ou fluorfosfato.

$\mathrm{Na}$ Odontologia, um dos primeiros relatos da utilização dos bisfosfonatos foi o estudo realizado por Schmidt e Rowe (1987), que analisaram a possibilidade de uma alternativa para 0 tratamento de inflamações crônicas periodontais em ratos, usando dois bisfosfonatos diferentes, administrados por via subcutânea. Analisados os valores encontrados nos cortes histológicos, os autores concluíram que os locais tratados com os bisfosfonatos foram evidenciados e estatisticamente mais altos.

O efeito do alendronato de sódio em periodontites experimentais em macacos foi o objetivo de um estudo clínico e radiográfico realizado por Brunsvold et al. (1992), Os autores afirmam que as doenças periodontais são iniciadas por reações inflamatórias e imunológicas do hospedeiro, caracterizadas pela perda do tecido conjuntivo e osso alveolar, estando a perda do osso alveolar associada com o balanço normal entre reabsorção e 
formação óssea. Os resultados mostraram que após 16 semanas, por análise radiográfica, o alendronato na concentração de $0,05 \mathrm{mg} / \mathrm{Kg}$ inibiu significantemente a perda de densidade mineral do osso alveolar.

Em avaliação histológica usando movimentação ortodôntica estandardizada em ratos, e com administração sistêmica diária via subcutânea de um bisfosfonato, realizada por Igarashi et al. (1994), mostrou histologicamente que tanto a reabsorção óssea alveolar quanto a radicular foram inibidas e que nos animais experimentais, uma menor quantidade de osteoclastos era observada na superfície óssea alveolar.

Nesse mesmo ano, Adachi et al. (1994) examinaram o efeito da administração tópica do risendronato, na movimentação ortodôntica de dentes de ratos. A solução do risendronato era injetada a cada 3 dias durante 3 semanas no sub-periósteo na região do primeiro molar superior direito, enquanto que, na região homóloga, recebia cloreto de sódio a $0,9 \%$ (controle). Os autores concluíram que a administração tópica causou uma significante redução na movimentação dental após a aplicação da força ortodôntica e que o risendronato não alterou o crescimento geral e nem 0 longitudinal da tíbia dos animais.

A pesquisa realizada por Weinreb et al. (1994) analisou histomorfometricamente os efeitos do alendronato de sódio em periodontites experimentais em macacos. Foram administradas por via endo venosa duas concentrações diferentes do alendronato além do placebo. Os resultados histomorfométricos juntamente com as análises radiográficas mostraram que a dose de $0.05 \mathrm{mg} / \mathrm{Kg}$ reduziu significantemente a periodontite experimental 
e que não se percebeu nenhum efeito da medicação usada na concentração de $0.25 \mathrm{mg} / \mathrm{Kg}$. Os autores sugeriram que o alendronato, assim como os hormônios e fatores de crescimento, apresentam uma resposta bifásica, ou seja, diferentes concentrações de alendronato podem dar diferentes resultados, daí a necessidade de mais estudos para se determinar a relação dose-efeito desse fármaco.

O uso do alendronato em cães da raça Beagle com periodontite ativa demonstrou claramente por análise histomorfométrica, que a administração desse bisfosfonato reduziu a perda óssea associada com a progressão da periodontite e que houve um aumento da densidade óssea, podendo então, ser um coadjuvante ao tratamento periodontal em pacientes adultos e ser adicionado ao arsenal dos periodontistas (REDDY et al., 1995).

Posteriormente, Igarashi et al. (1996), realizaram um outro estudo em ratos, onde avaliaram os efeitos da administração tópica do risendronato na reabsorção radicular durante a movimentação ortodôntica e no reparo das superfícies radiculares reabsorvidas. Os autores constataram que a administração tópica causou uma nibição significativa e dose-dependente da reabsorção radicular após a força ortodôntica, e também a evidenciação da não inibição do processo reparativo das raízes reabsorvidas.

Yaffe et al. (1997), avaliaram a afetividade da aplicação tópica em sítio cirúrgico do alendronato na redução da reabsorção óssea. Sendo esse o primeiro relato que demonstrou a efetividade da aplicação tópica do alendronato na prevenção de processos de reabsorção após cirurgias de retalho muco-perióstea, uma vez que muitos relatos mostravam que a 
cirurgia periodontal estimulava a atividade osteoclástica com quantidades variáveis de perda da crista óssea alveolar. Tanto Frost (1989) como Yaffe et al. (1997), descrevem esta reação como fenômeno regional acelerado. Este fenômeno é uma explosão transitória do processo de remodelação localizado na ferida cirúrgica do osso cortical. Foi sugerido que os osteoclastos e osteoblastos, que formam um novo osso a cada estágio, não existem em quantidade suficiente para promover a reparação óssea póscirurgia. Tal fenômeno é também observado em animais após cirurgias de implante.

Meraw e Reeve (1999), avaliaram em cães os efeitos do alendronato em áreas de regeneração óssea ao redor de implantes. Foram utilizados implantes que receberam alendronato na superfície, comparados com implantes convencionais. Os autores concluíram que a aplicação local da droga resultou em aumento significativo da quantidade de osso formado ao redor dos implantes.

A possibilidade de utilização dos bisfosfonatos para o controle de reabsorções pós-traumatismo dental, foi inicialmente investigada por Liewehr et al. (1995). Os autores realizaram estudo in vitro para verificar o efeito de dois bisfosfonatos e do Nitrato de Galium na reabsorção dentinária. Foram utilizadas células osteoclásticas de pintinhos pré-natais, cultivadas em discos de dentina humana. Esses discos ficaram imersos em soro fisiológico (controle), nas respectivas soluções dos bisfosfonatos e na solução de Nitrato de Galium, por 48 horas. A reabsorção foi mensurada através de microscopia óptica e eletrônica, pela contagem do número de lacunas de 
reabsorção produzidas pelas células. Os autores constataram que a utilização dos bisfosfonatos reduziu significantemente a reabsorção dentinária, daí sugerirem um tratamento experimental para prevenir ou pelo menos adiar a reabsorção substitutiva em dentes avulsionados.

Um outro estudo in vitro realizado por Sommercorn et al. (2000), avaliou o efeito do alendronato na neoformação de dentina em dentes humanos com ápices imaturos. Dentes molares e pré-molares humanos com ápices não totalmente formados foram cultivados em meio de cultura tecidual por 60 dias. Foi utilizada uma concentração de alendronato a $10^{-9} \mathrm{M}$. O progresso do crescimento em cultura foi observado usando microscopia óptica invertida e as secções histológicas foram analisadas com microscópio de fluorescência Leitz. Os resultados mostraram que o grupo com alendronato, obteve crescimento $57,15 \%$ maior na região apical do que o grupo controle e que o crescimento na região apical foi significantemente maior que nas outras áreas de mensuração para ambos os grupos controle e alendronato. Verificaram também, que a deposição de dentina foi mais lenta nos primeiros 30 dias quando comparadas aos 30 dias restantes e que a concentração do alendronato a $10^{-9} \mathrm{M}$, acelerou claramente a deposição de tecido mineralizado nos ápices imaturos.

Com relação à utilização do alendronato de sódio no traumatismo dental, uma pesquisa realizada por Levin et al. (2001), avaliou a ação tópica do alendronato na reabsorção radicular de dentes reimplantados em cães. 82 raízes de pré-molares de 5 cães foram endodonticamente tratadas, 
restauradas e depois avulsionadas intencionalmente e tratadas da seguinte forma antes do reimplante:

12 raízes, com sulco na lingual
e reimplante imediato $\left\{\begin{array}{l}6 \text { raízes por } 5 \text { minutos em HBSS } \\ 6 \text { raízes por } 5 \text { minutos em HBSS + ALN }\end{array}\right.$ 35 raízes, 45 minutos
a seco $\left\{\begin{array}{l}16 \text { raízes por } 5 \text { minutos em HBSS } \\ 19 \text { raízes por } 5 \text { minutos em HBSS + ALN }\end{array}\right.$ 35 raízes, 60 minutos
a seco $\left\{\begin{array}{l}16 \text { raízes por } 5 \text { minutos em HBSS } \\ 19 \text { raízes por } 5 \text { minutos em HBSS + ALN }\end{array}\right.$ HBSS - Solução salina balanceada de Hanks ALN - alendronato de sódio

Após o reimplante, não foram feitas contenções e os cães foram sacrificados após 4 meses, quando suas raízes foram preparadas para análise histológica. Os resultados mostraram que a reparação cementária ocorreu em todas as 12 raízes sulcadas artificialmente, indicando que o meio não inibiu a cementogênese, e que as raízes mantidas no alendronato tiveram uma reparação estatisticamente mais significante do que as raízes mantidas em HBSS sem alendronato. O meio com alendronato também resultou em perda significativamente menor de massa radicular devido à reabsorção, comparada àqueles dentes embebidos em HBSS sem 
alendronato, concluindo dessa forma, que as raízes que permaneceram no alendronato antes do reimplante apresentaram melhores resultados quanto à reparação das raízes e também menor perda de massa radicular por reabsorção.

Um estudo realizado por Kum et al. (2003), partiu da premissa que a reabsorção externa radicular, por ser uma possível conseqüência do traumatismo dental, e estar associada à presença de bactérias, reações inflamatórias e por uma intensa atividade osteoclástica, e pode avaliar a capacidade do alendronato e da solução Taurine, na inibição in vitro de osteoclastos induzidos pela bactéria Porphyomonas gingivalis. As concentrações de alendronato utilizadas foram: $10^{-7}, 10^{-6}$ e $10^{-5} \mathrm{M}$, enquanto que as de Taurine foram de $4 \mathrm{mM}, 8 \mathrm{mM}$ e $12 \mathrm{mM}$. Os resultados mostraram que nenhum efeito citotóxico foi evidenciado em todas as concentrações de ambas, indicando que as duas soluções apresentam um efeito inibitório nos osteoclastos induzidos por essas bactérias.

A literatura mostra que a conduta inicial adotada no atendimento emergencial nos casos de avulsão é de suma importância para o prognóstico do caso, onde as vantagens do reimplante imediato são evidentemente claras. No caso do aparecimento de reabsorções, se faz necessário uma melhor compreensão desse processo reabsortivo, permitindo uma melhor abordagem quanto à utilização de medicações alternativas para esses casos.

Reconhecida à possibilidade de utilização desta medicação, cabe inicialmente considerar alguns estudos de citotoxicidade in vitro, por meio de 
técnicas de cultura celular, que tem o propósito de conhecer o potencial citotóxico, permitindo um melhor controle das condições experimentais. Para indicar a existência do dano celular podem ser utilizadas, além da descrição da morfologia celular, diferentes evidências tais como: efeitos de membrana, atividade celular e índice de proliferação.

Ao se investigar o mecanismo de resposta biológica de qualquer medicamento é necessário, avaliar os efeitos biológicos das substâncias liberadas separadamente e em combinação, a interação destas com o meio biológico e os efeitos sinérgicos ou antagônicos das drogas.

Freshney (2000), relata que os ensaios de cultura de células podem ser divididos em duas classes: (1) Resposta imediata ou de curto prazo, tal como alteração na permeabilidade da membrana ou pertubação de uma via metabólica, e (2), sobrevivência de longo prazo, geralmente medida pela retenção da capacidade de auto-renovação ou sobrevivência em estado alterado. Testes de longo prazo geralmente são usados para demonstrar a capacidade metabólica ou proliferativa das células após influência tóxica, cujo objetivo é medir a sobrevivência, uma vez que essa implica na retenção da capacidade regenerativa da célula.

Assim sendo, de acordo com a literatura pesquisada, sobre a ação dos bisfosfonatos, e mais especificamente sobre o alendronato, justifica-se avaliar a ação e citotoxicidade desse fármaco através de cultura de células, para fornecer embasamento para futuros trabalhos experimentais relacionados com as alterações celulares e histológicas que ocorrem quando de um traumatismo dental severo. 


\section{PROPOSIÇÃO}

O objetivo do estudo, é avaliar a citotoxidade do alendronato de sódio, utilizando-o em diferentes concentrações em cultura celular de fibroblastos de ligamento periodontal de humanos, com o intuito de analisar se esse medicamento pode ser utilizado como medicação intracanal nos casos de traumatismo dentário e atuar na prevenção ou remissão dos processos reabsortivos. 


\section{MATERIAL E MÉTODOS}

Foram utilizados fibroblastos de ligamento periodontal originados de humanos, de linhagem contínua de células com alta inibição de contato, cedidos pelo laboratório de Pesquisa Básica do Departamento de Dentística da FOUSP.

O presente estudo foi aprovado pelo Comitê de Ética em Pesquisa da FOUSP com o parecer $n^{\circ} 88 / 03$ e protocolo 79/03 (ANEXO A).

Todos os experimentos foram realizados sob capela de fluxo laminar.

\subsection{Material}

- Capela de fluxo laminar (VECO - Campinas, SP, Brasil)

- Tubos criogênicos (Sigma)

- Banho-Maria a $37^{\circ} \mathrm{C}$ (Fanem, SP)

- Di-metil-sulfóxido - DMSO (Sigma)

- Meio de cultura celular de Eagle modificado por Dulbecco (DMEM) (Sigma)

- Centrífuga Excelsa Baby I, modelo 206 (Fanem, SP)

- Frascos plásticos de cultivo celular $-25 \mathrm{~cm}^{2}$ (Costar)

- Soro fetal bovino (Sigma) 
- Solução antibiótica/antimicótica (Sigma)

- Incubadora com controle de temperatura/pressão (Forma Scientific)

- Microscópio invertido de fase (Axiovert 25 ZEISS)

- Pipetas de vidro graduadas (Costar)

- Pipetas Pasteur (Costar)

- Pipetas Gilson

- Solução tampão fosfato-salina sem cálcio e sem magnésio (PBSA) (Sigma)

- Solução de tripsina 0,25\% (Sigma)

- Tubos de ensaio (Costar)

- Azul de Trypan a 0,4\% (Sigma)

- Câmara de Neubauer (Baxter)

- Placas de Petri (35 mm de diâmetro) (Costar)

- Filtros Milipore $(0,22 \mu$ de diâmetro)

- Agitador Mecânico Vortex-Genie2 (A .Daigger \& Co.,INC )

- Alendronato de sódio (Fórmula e Ação Ltda., São Paulo) 


\subsection{Métodos}

4.2.1 Cultivo celular e determinação do número de células existentes no frasco original

Um tubo criogênico contendo as células, foi descongelado rapidamente (60 segundos) em banho-maria a $37{ }^{\circ} \mathrm{C}$. Para remover a substância crioprotetora (Di-metil-sulfóxido - DMSO), o conteúdo da ampola foi transferido para um tubo de ensaio contendo $10 \mathrm{~mL}$ de meio de cultura e centrifugado a $300 \mathrm{~g}$ durante 5 minutos, à temperatura ambiente. $\mathrm{O}$ sobrenadante foi removido e o precipitado de células resultantes da centrifugação, foi ressuspendido em $1 \mathrm{~mL}$ de meio de cultura fresco e transferido para um frasco plástico de cultivo celular de $25 \mathrm{~cm}^{2}$ contendo 5 $\mathrm{mL}$ de meio de cultura fresco. O meio de cultura utilizado foi o meio de Eagle modificado por Dulbecco (DMEM), contendo $10 \%$ de soro fetal bovino e $1 \%$ de solução antibiótica-antimicótica.

As células foram mantidas em estufa a $37^{\circ} \mathrm{C}$, numa atmosfera úmida contendo $95 \%$ de ar e $5 \%$ de $\mathrm{CO}_{2}$. A monitoração do crescimento celular foi feita a cada 24 horas, utilizando-se de um microscópio invertido de fase. Os subcultivos foram realizados quando a monocamada celular tornourse subconfluente. O meio dos frascos foi aspirado e a monocamada celular 
lavada uma vez com uma solução tampão fosfato-salina sem cálcio e sem magnésio (PBSA) de $\mathrm{pH} 7.2$.

A seguir, as células foram separadas com $2 \mathrm{~mL}$ de uma solução de tripsina $0,25 \%$ durante 5 minutos a $37^{\circ} \mathrm{C}$. A tripsina foi então inativada com $5 \mathrm{~mL}$ de meio de cultura contendo soro fetal bovino e as células em suspensão transferidas para um tubo de ensaio e centrifugadas a $300 \mathrm{~g}$ durante 5 minutos à temperatura ambiente. $O$ sobrenadante foi aspirado e os precipitados de células resultantes da centrifugação foram resuspendidas em $1 \mathrm{~mL}$ de DMEM fresco. Para a perpetuação da linhagem celular, frações dessa suspensão de células foram sub-cultivadas em novos frascos, procedimento esse que deu origem a novas passagens da cultura (Figura 4.1).

Para a determinação do número de células existentes nos frascos originais, os precipitados foram ressuspendidos em 1,0 mL de PBSA e 0,1 $\mathrm{mL}$ dessa suspensão celular foi dispensado em tubo de ensaio, sendo adicionado 0,8 $\mathrm{mL}$ de PBSA e 0,1 $\mathrm{mL}$ de azul de Trypan. Posteriormente, algumas gotas desta suspensão celular foram transferidas para 0 hemocitômetro (câmara de Neubauer) e a seguir, com ajuda do microscópio invertido de fase realizou-se a contagem celular, onde as células mortas foram evidenciadas pela coloração azulada, enquanto as vivas mantiveramse despigmentadas (Figura 4.2). 


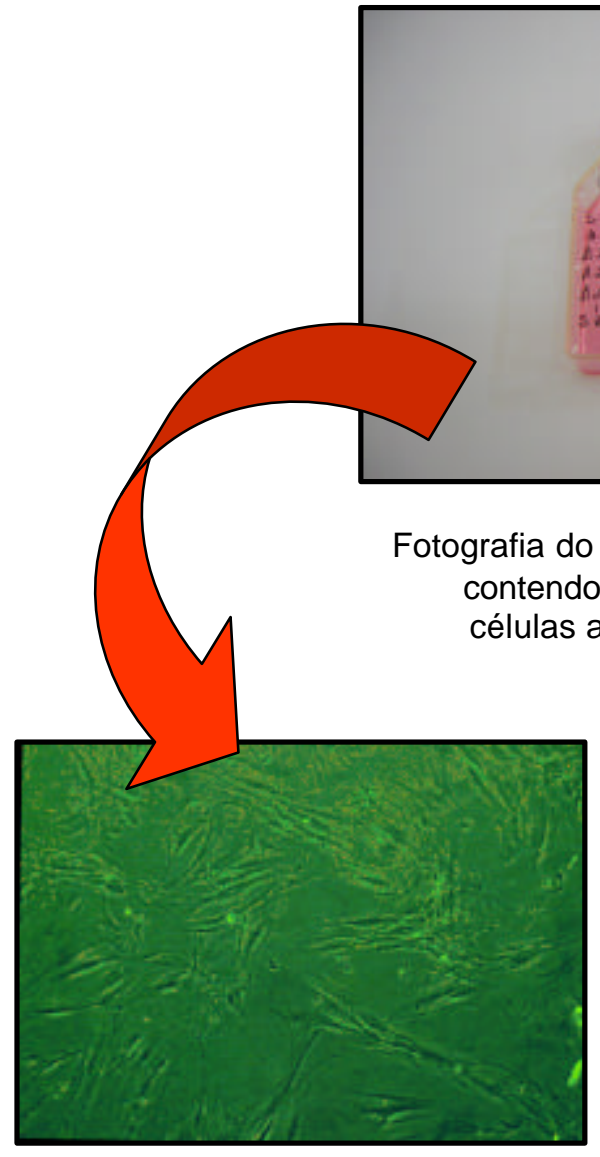

Células aderidas

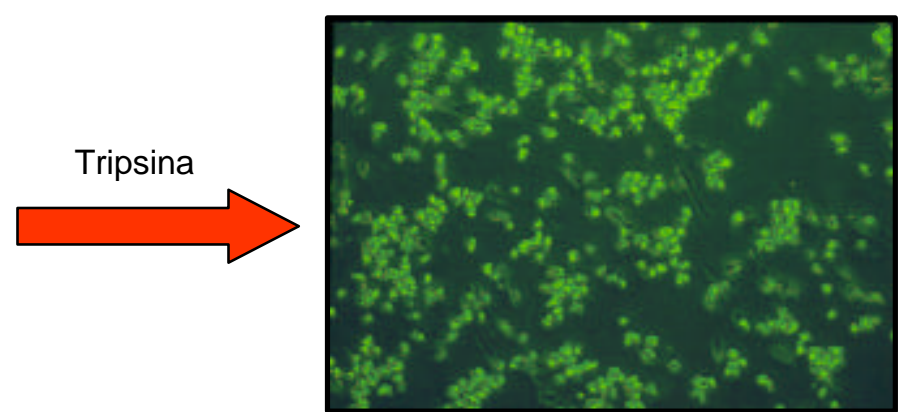

Células em suspensão

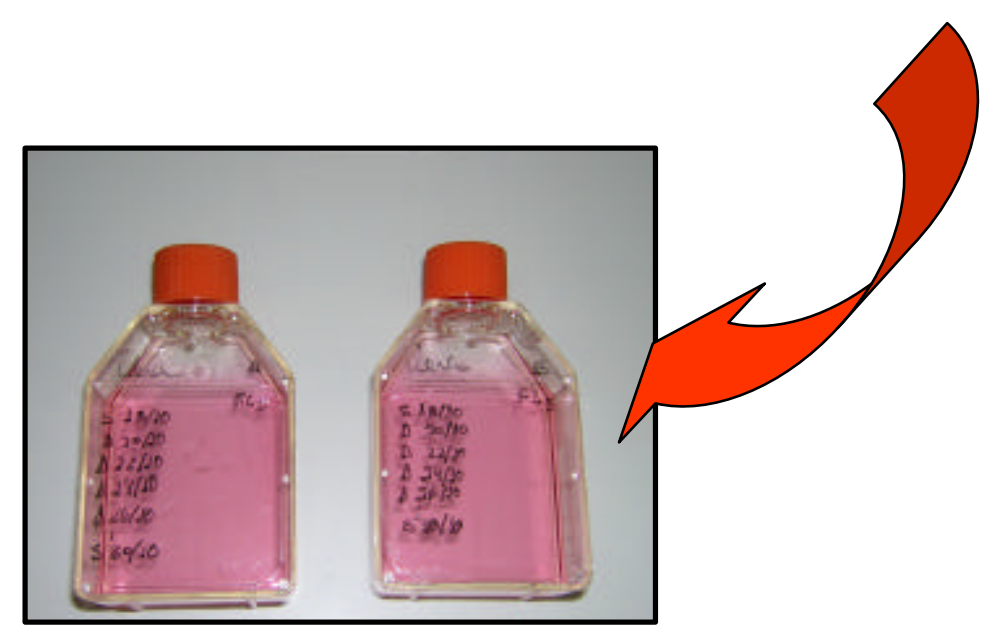

2 novos frascos de cultura Nova passagem

Figura 4.1 - Representação esquemática de sub-cultivo, para a realização dos testes de curto e longo prazos 


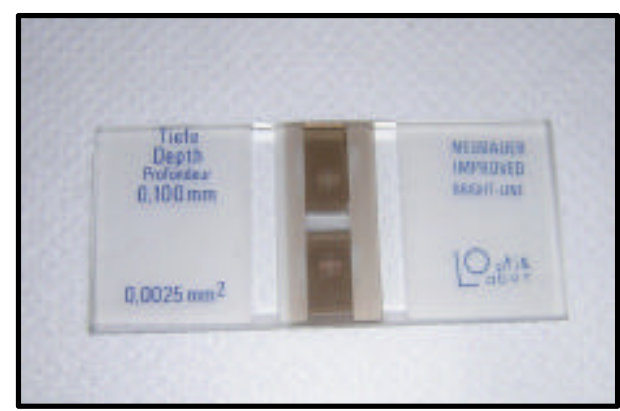

Fotografia da câmara de Neubauer utilizada para contagem de células no microscópio invertido de fase

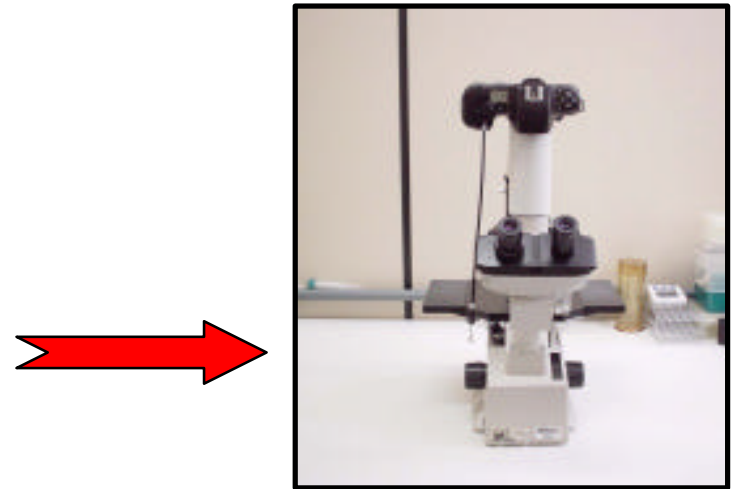

Microscópio invertido de fase
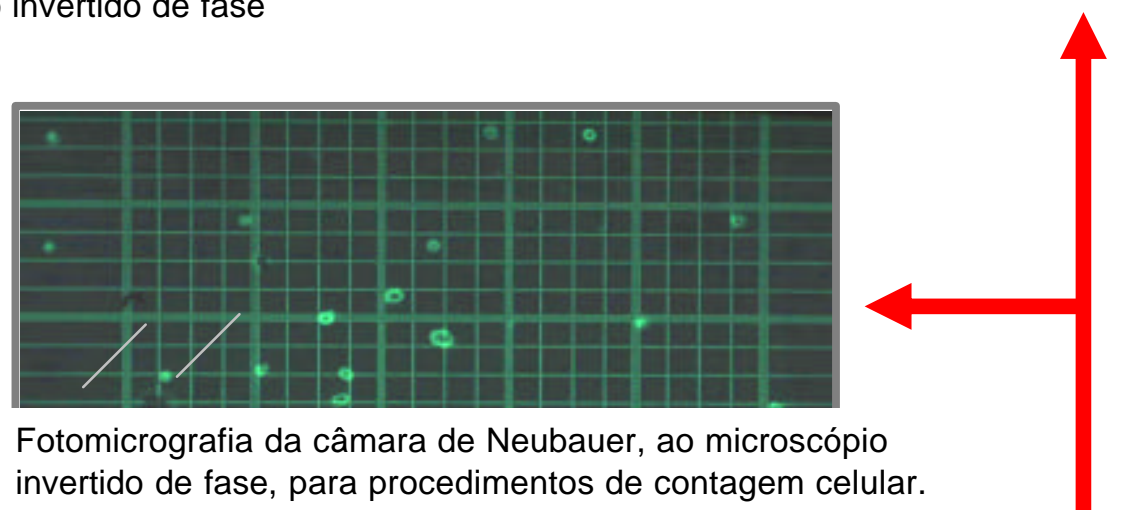

Fotomicrografia da câmara de Neubauer, ao microscópio invertido de fase, para procedimentos de contagem celular. Células mortas, coradas pelo azul de Trypan (seiás).

Figura 4.2 - Representação do processo de contagem celular

O número total de células provenientes do frasco original foi obtido através da seguinte equação:

$$
\mathrm{N}^{\circ} \text { de células }=\frac{\mathrm{N}^{\circ} \text { total de células contadas } \times \text { Diluição } \times 10^{4}}{\mathrm{~N}^{\circ} \text { de quadrados usados para a contagem }}
$$

A seguir, a suspensão celular restante $(0,9 \mathrm{~mL})$ foi centrifugada e 0 sobrenadante foi aspirado e o novo precipitado de células resultante da centrifugação foi ressuspendido em $1 \mathrm{~mL}$ de meio de cultura (DMEM) fresco. Dependendo do número de células existentes nos frascos originais, foi adicionado a essa suspensão uma determinada quantidade de DMEM a fim de obter $1 \times 10^{3}$ células em cada $0,1 \mathrm{~mL}$. Tal suspensão de células foi replaqueada em placas de Petri de $35 \mathrm{~mm}$ de diâmetro, onde as células 
aderiram e cresceram. Para a manutenção da viabilidade das células, a troca dos meios de cultivo dos frascos e das placas de Petri foi feita a cada dois dias.

\title{
Grupos experimentais:
}

\author{
Grupo I - Fibroblastos de ligamento periodontal cultivado \\ em meio DMEM sem adição de substância (controle) \\ Grupo II - Fibroblastos de ligamento periodontal cultivados \\ em meio DMEM com ALN $^{*} 10^{-5} \mathrm{M}$ \\ Grupo III - Fibroblastos de ligamento periodontal cultivados \\ em meio DMEM com $\mathrm{ALN}^{*} 10^{-6} \mathrm{M}$ \\ Grupo IV - Fibroblastos de ligamento periodontal cultivados \\ em meio DMEM com $\mathrm{ALN}^{*} 10^{-7} \mathrm{M}$ \\ $\mathrm{ALN}^{*}$ alendronato de sódio
}

\subsection{Preparo das substâncias}

Dentro da capela de fluxo laminar, foi preparada uma solução estoque de alendronato de sódio em DMEM na concentração de $10{ }^{-4} \mathrm{M}(0,325 \mathrm{~g}$ em $100 \mathrm{~mL}$ ). A seguir, essa solução foi aquecida em banho-maria a $37{ }^{\circ} \mathrm{C}$ durante 15 minutos e depois colocada no agitador mecânico para a completa diluição da droga no meio. Após a diluição da droga, passou-se novamente para a capela de fluxo laminar, onde a solução foi esterilizada em filtro 
Milipore (poros de 0,22 micrômetros) e acondicionada em frasco autoclavado. As concentrações utilizadas no experimento $\left(1 \times 10^{-5}, 1 \times 10^{-6}\right.$ e $1 \times 10^{-7} \mathrm{M}$ ), foram obtidas por diluições seriadas, a partir da solução de estoque $\left(1 \times 10^{-4} \mathrm{M}\right)$. Essas concentrações foram escolhidas após um estudo piloto, onde concentrações de $10^{-2}$ a $10^{-8} \mathrm{M}$ foram analisadas, e somente as diluições a partir de $10^{-5} \mathrm{M}$ se mostraram viáveis. Todas as soluções foram preparadas e utilizadas no momento do experimento, quando do ensaio de curto prazo ou a cada troca do meio na avaliação de longo prazo.

\subsection{Teste de viabilidade celular (curto prazo)}

Nesta fase do experimento, as células crescidas nos frascos foram tripsinizadas e contadas para a determinação do número de células existentes no frasco original, conforme já descrito anteriormente. $\mathrm{O}$ restante da suspensão celular foi centrifugada novamente e resuspendida em um novo meio na quantidade para se obter $1 \times 10^{3}$ células em cada $0,1 \mathrm{~mL}$, para ser plaqueada nesta densidade em placas de Petri de $35 \mathrm{~mm}$ de diâmetro, contendo $2,0 \mathrm{~mL}$ de meio de cultura.

Decorrido o período de 72 horas, quando as culturas já estavam confluentes, o meio de cultura das placas foi trocado pelas novas soluções de DMEM com alendronato de sódio preparadas nas concentrações acima 
descritas. As placas de controle receberam somente o meio de cultura fresco (Figura 4.3).

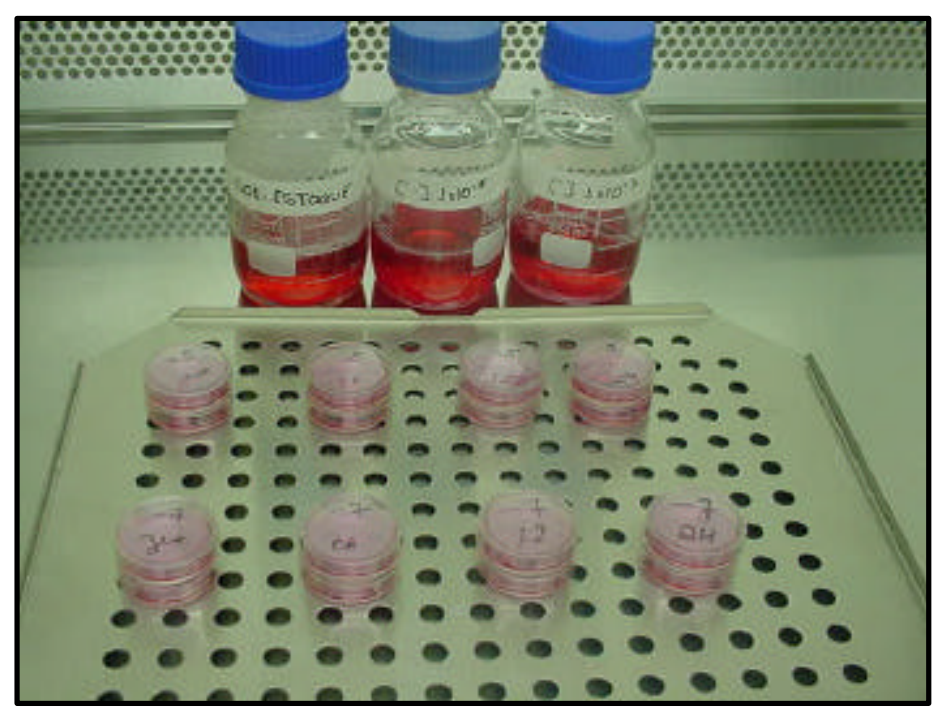

Placas de Petri contendo meio DME com concentrações de alendronato de sódio

Figura 4.3 - Fotografia das placas de Petri, dentro da capela de fluxo laminar

Após 1, 6, 12 e 24 horas de contato com as soluções descritas, as células de 3 placas de Petri para cada grupo e período experimental, totalizando 12 placas por solução testada, essas foram tripsinizadas e contadas em câmaras de Neubauer, utilizando para isso o microscópio invertido de fase.

Concluída essa etapa, foram realizadas curvas de porcentagem de viabilidade celular em função do tempo experimental, como descrito abaixo:

O número total de células viáveis foi obtido através da mesma sentença excluindo-se as células mortas coradas pela azul de Trypan a $0,4 \%$ : 
№ de células viáveis $=\frac{\text { № total de células vivas (não coradas) } \times \text { Diluição } \times 10^{4}}{№ \text { de quadrados usados para a contagem }}$

O percentual de viabilidade da população celular foi obtido pela fórmula a seguir:

$$
\text { Viabilidade celular }(\%)=\frac{\text { № total de células viáveis }}{\text { № total de células }} \times 100
$$

\subsection{Teste de sobrevivência celular (longo prazo)}

Para a realização desta fase do estudo, os fibroblastos originados dos frascos foram plaqueados na densidade de $1 \times 10^{3}$ células por placa de Petri de $35 \mathrm{~mm}$ de diâmetro, com $2 \mathrm{~mL}$ meio DMEM acrescido da solução a ser testada, na concentração pré-estabelecida. As culturas controle receberam somente DMEM fresco. Após 2, 4, 6, e 8 dias do contato com as soluções, as células foram tripsinizadas e contadas em câmara Neubauer, utilizandose o microscópio invertido de fase, perfazendo um total de 3 placas de Petri por período experimental e 12 placas por grupo.

Ao final de 8 dias do experimento foram realizadas curvas de crescimento e de percentagem de viabilidade celular em função do tempo, como realizados anteriormente, no teste de viabilidade celular. 


\subsection{Análise estatística}

Os dados em triplicata foram analisados estatisticamente pelo método paramétrico ANOVA, com diferenciação dos grupos pela comparação múltipla pelo método de Tukey, considerando o nível de 5\%. Foi utilizado o programa estatístico Minitab versão 14.12. 


\section{RESULTADOS}

O resultado morfológico da linhagem celular dos fibroblastos de ligamento periodontal (FL3), sob a ação do alendronato de sódio em várias concentrações $\left(10^{-5}, 10^{-6}\right.$ e $\left.10^{-7} \mathrm{M}\right)$, mostraram-se claramente evidenciadas nos períodos de 6 e 8 dias. Observamos o início da lise celular entre o quinto e o sexto dia (Figura 5.1), nas concentrações de $10^{-5} \mathrm{M}$ e $10^{-6} \mathrm{M}$, enquanto que na concentração de $10^{-7} \mathrm{M}$ e grupo controle, as células apresentavamse com suas características morfológicas preservadas. No oitavo dia (Figura 5.2), observamos que as células nas concentrações mais elevadas encontravam-se totalmente desagregadas das placas de Petri e com lise total das membranas citoplasmáticas celulares.

Os dados originais do experimento (viabilidade celular e sobrevivência celular), que constam nos Apêndices A e B, foram inicialmente submetidos a testes para verificar a igualdade das variâncias e a normalidade dos resíduos pelos testes de Levene e Anderson-Darling respectivamente. Confirmada a distribuição normal, com nível descritivo de 0,370 e 0,040 para os experimentos de curto e longo prazo respectivamente, os resultados em triplicata foram analisados estatisticamente para cada fase desta pesquisa pela análise de variância (ANOVA, com significância de 5\%), para dois fatores fixos (tempo x concentração), além da verificação das diferenças entre os grupos. 
Controle - G I

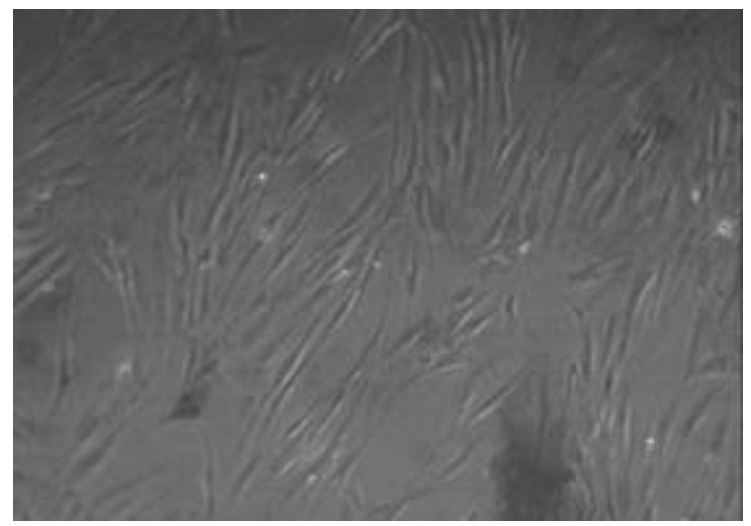

$10^{-6} \mathrm{M}-\mathrm{G}$ III

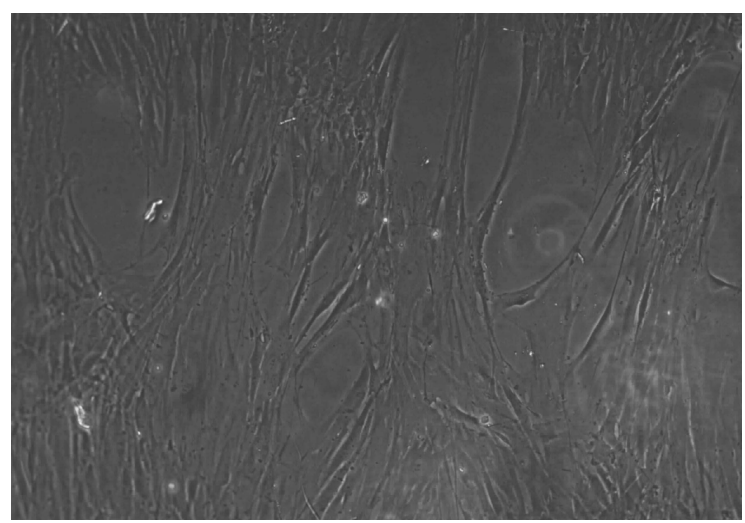

$10^{-5} \mathrm{M}-\mathrm{G} \|$

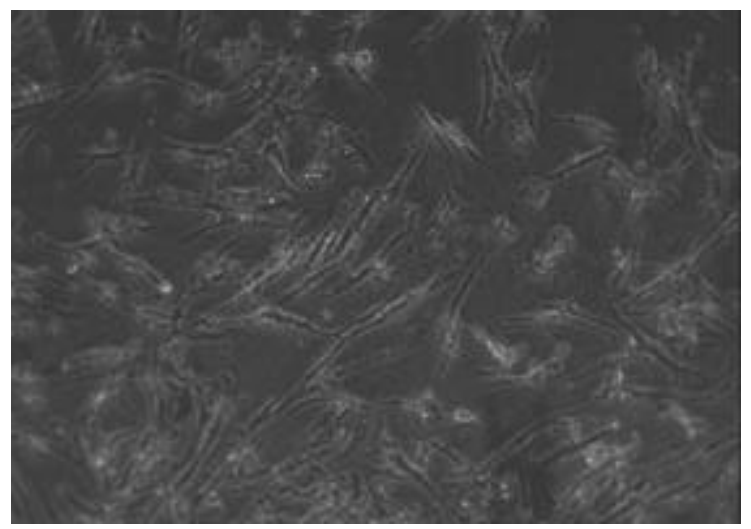

$10^{-7} \mathrm{M}-\mathrm{G}$ IV

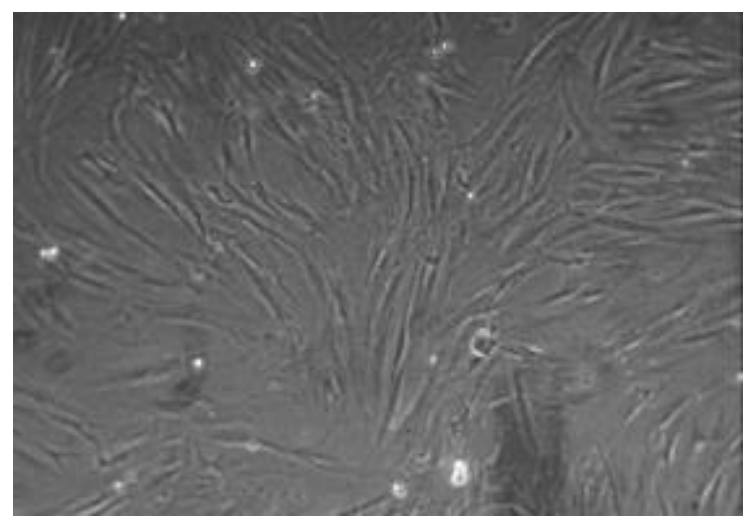

Figura 5.1- Cultura de fibroblastos FL3 no período de 6 dias em contato com as concentrações de ALN. O grupo controle (G I), apresenta-se assim como o grupo G IV, com grande número de células e com manutenção da membrana citoplasmática, enquanto que nos grupos G II e G III o número de células viáveis diminuiu e já se nota alterações nas membranas citoplasmáticas celulares do grupo G II. 


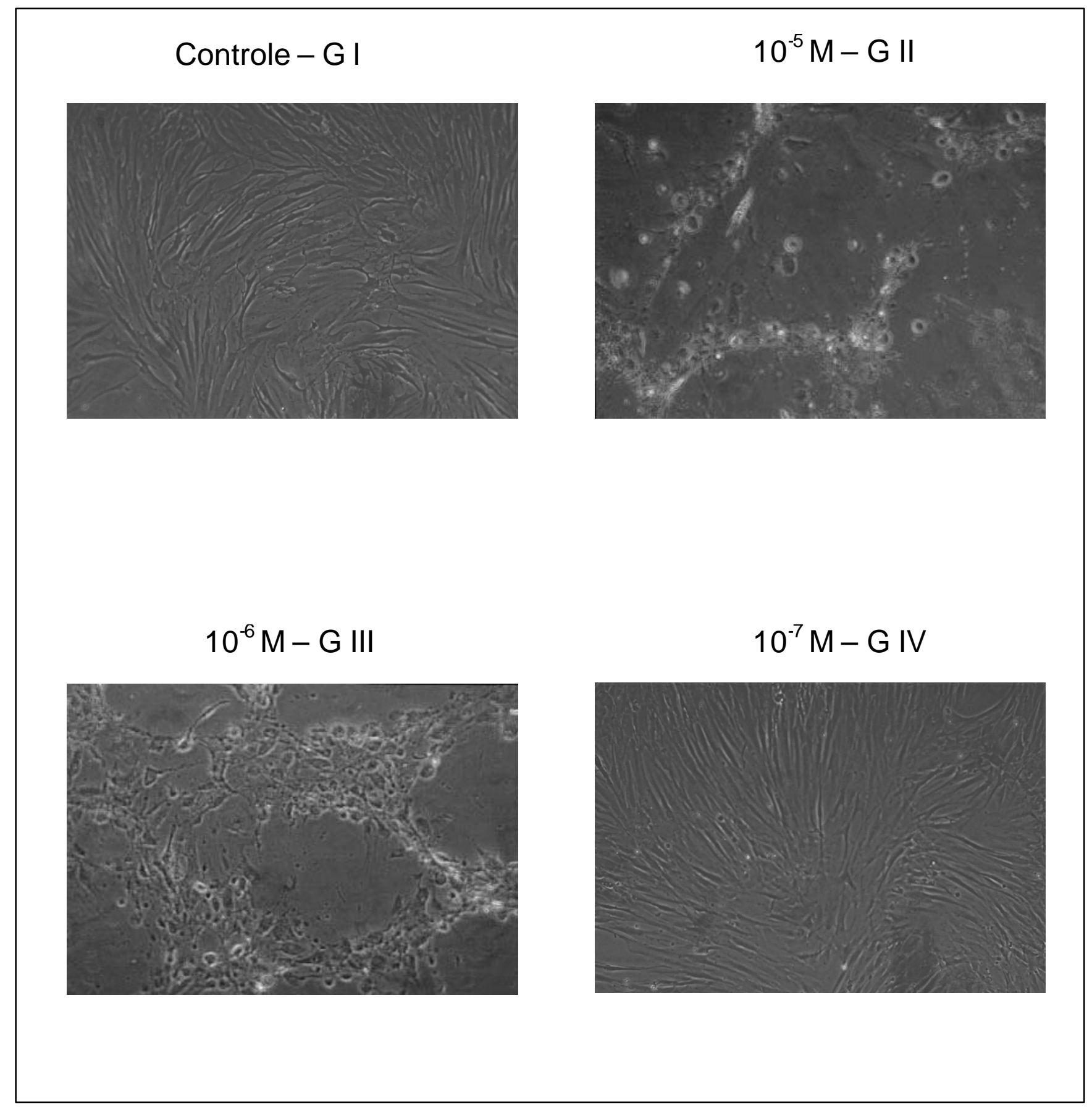

Figura 5.2 - Cultura de fibroblastos FL3 no período de 8 dias em contato com as concentrações de ALN. O grupo controle (G I) e o grupo G IV, apresentamse com viabilidade celular, enquanto que nos grupos G II e G III observa-se alterações nas membranas citoplasmáticas e lise celular. 
Fase 1 - Avaliação da viabilidade celular

Na Tabela 5.1, temos as médias e desvios padrão para os percentuais, também representado no Gráfico 5.1

Tabela 5.1 - Médias e Desvios padrão (entre parênteses) para o percentual de células sobreviventes - curto prazo

\begin{tabular}{l|llll}
\hline \multirow{2}{*}{ Grupos } & \multicolumn{4}{|c}{ Tempo } \\
\cline { 2 - 5 } & Oh & $6 \mathrm{~h}$ & $12 \mathrm{~h}$ & $24 \mathrm{~h}$ \\
\hline Controle-G I & $92,5(1,3)$ & $90,8(0,8)$ & $92,5(3,5)$ & $91,9(1,1)$ \\
G II & $95,2(3,1)$ & $75,1(6,0)$ & $62,2(0,8)$ & $63,1(0,5)$ \\
G III & $91,4(1,9)$ & $86,7(4,8)$ & $87,7(2,2)$ & $85,9(1,3)$ \\
G IV & $93,1(3,4)$ & $95,4(2,6)$ & $88,5(2,9)$ & $93,9(1,8)$ \\
\hline
\end{tabular}

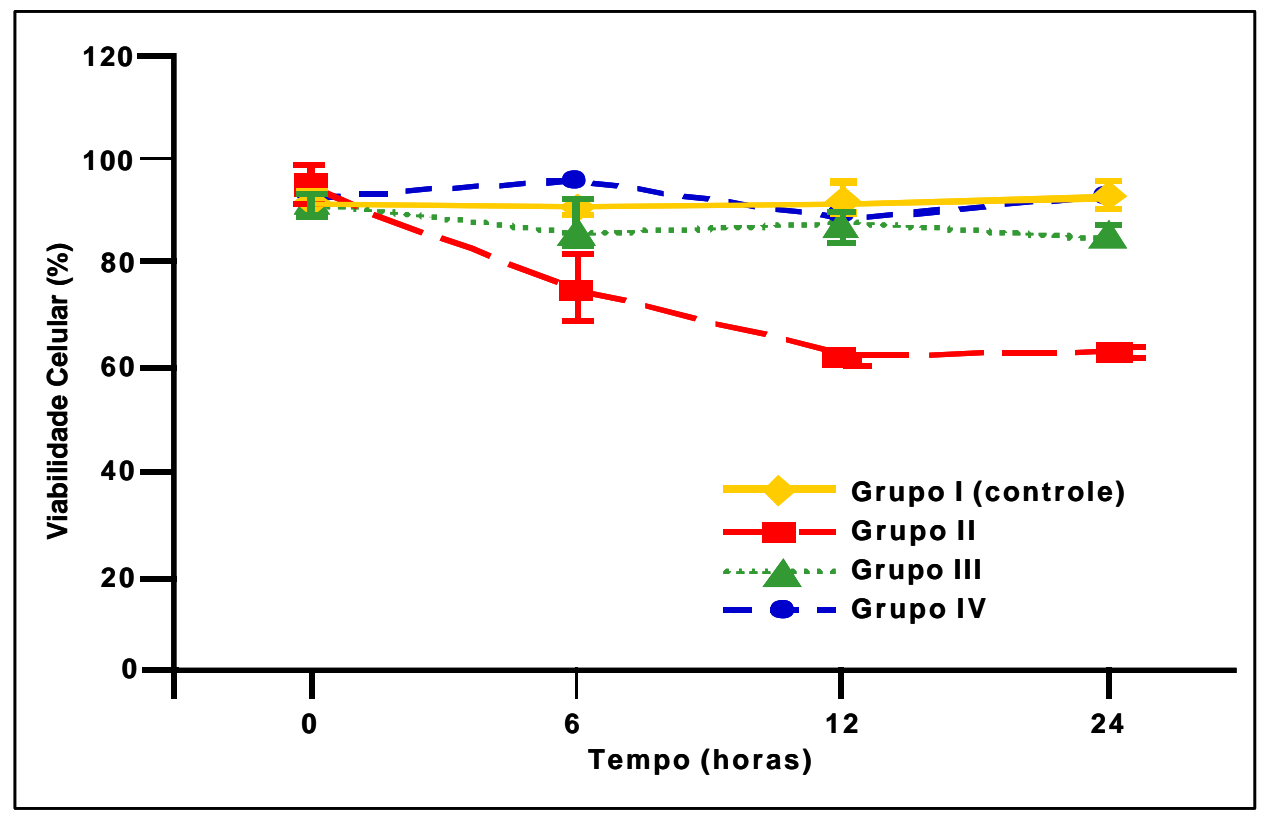

Gráfico 5.1 - Médias \pm 1 e desvio padrão para os percentuais de células sobreviventes - curto prazo

Pela tabela e gráfico acima, podemos observar que: 
- $\quad$ Os grupos G I, G III e G IV, apresentam comportamento semelhante variando o percentual ao longo do tempo entre $95 \%$ e $85 \%$.

- $\quad$ O G II apresentourse bem diferente dos demais com uma forte queda em 6 h e 12 h e estabilizando no patamar de $60 \%$ até às $24 \mathrm{~h}$.

- A variabilidade dos grupos foi aparentemente diferente entre si mas sem alguma lógica definida a não ser para o G IV que se mostrou estável.

Na Tabela 5.2 temos o resultado da ANOVA, onde verificamos que a coluna importante é a do nível descritivo, pela qual concluímos que existe interação significativa entre os grupos e o tempo, ou seja, a diferença entre os grupos varia ao longo do tempo.

Tabela 5.2 - Análise de variância para percentual - Curto prazo

\begin{tabular}{|c|c|c|c|c|c|}
\hline $\begin{array}{l}\text { Fonte de } \\
\text { Variação }\end{array}$ & $\begin{array}{l}\text { Graus de } \\
\text { liberdade }\end{array}$ & $\begin{array}{l}\text { Soma de } \\
\text { quadrados }\end{array}$ & $\begin{array}{l}\text { Quadrados } \\
\text { médios }\end{array}$ & $\begin{array}{l}\text { Estatística } \\
\mathrm{F}\end{array}$ & $\begin{array}{l}\text { Nível } \\
\text { descritivo }\end{array}$ \\
\hline Tempo & 3 & 782,12 & 260,71 & 32,93 & 0,000 \\
\hline Grupo & 3 & 2752,46 & 917,49 & 115,89 & 0,000 \\
\hline Tempo * Grupo & 9 & 1479,89 & 164,43 & 20,77 & 0,000 \\
\hline Resíduo & 32 & 253,34 & 7,92 & & \\
\hline Total & 47 & $\overline{5267,81}$ & & & \\
\hline
\end{tabular}

Para verificarmos qual grupo é diferente de qual, fizemos uma comparação múltipla pelo método de Tukey, onde todos os grupos foram comparados dois a dois, com o resultado geral da análise na mostrado na Tabela 5.3 


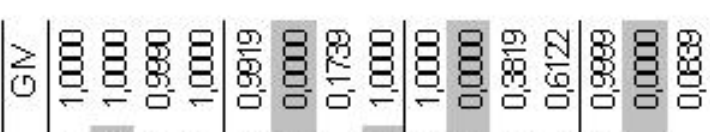

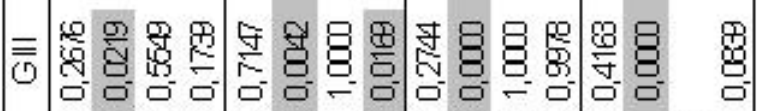

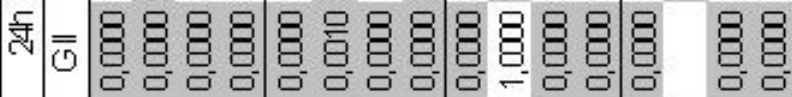

$\overline{9}$

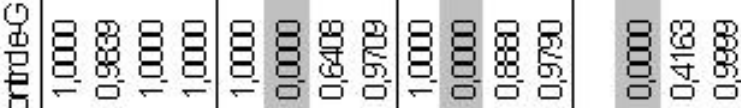

8

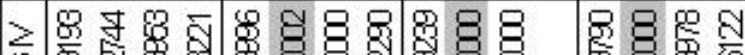

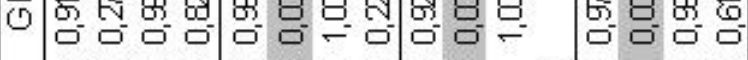

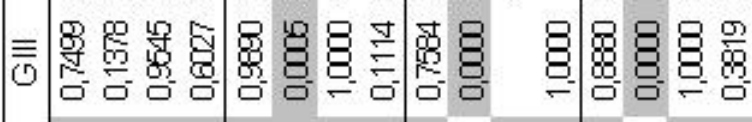

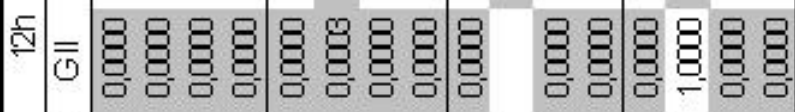

$\overline{0}$

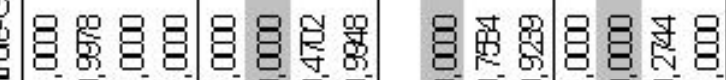

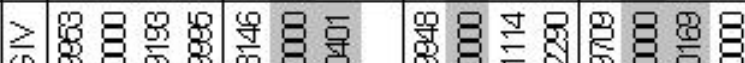

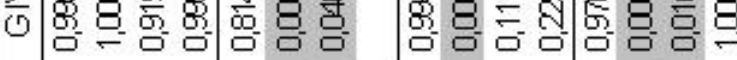

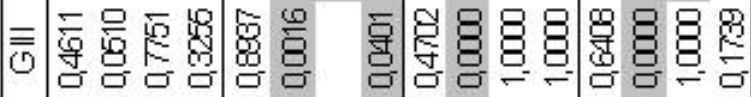

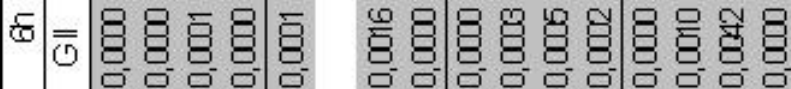

$\overline{0}$

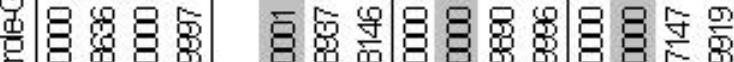

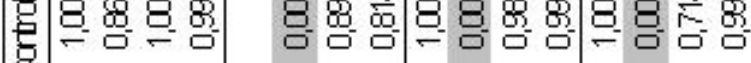

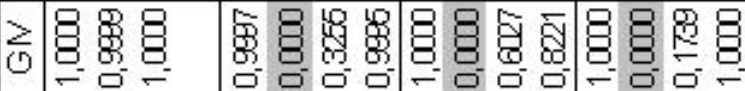

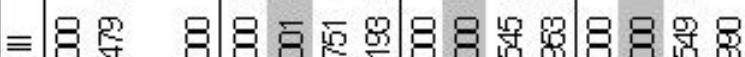

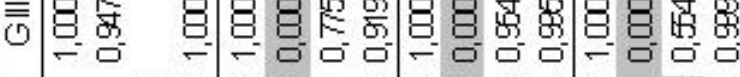

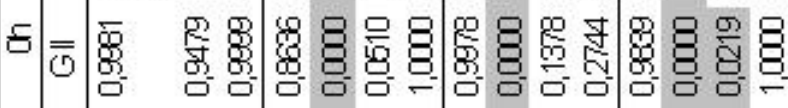

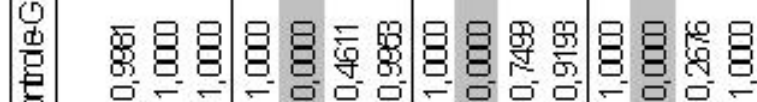

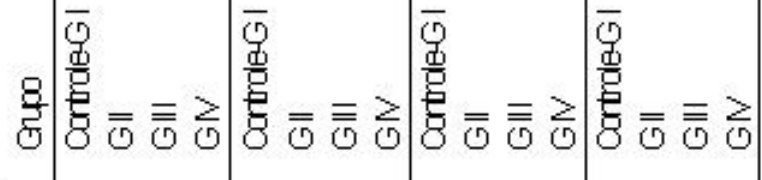
㝕

兵

5

占

腐 
Pela tabela podemos observar que:

- Ao longo do tempo os grupos G I, G III e G IV, não tiveram alteração significativa, mas o mesmo não acontece com o G II onde não temos diferença somente entre os tempos $12 \mathrm{~h}$ e $24 \mathrm{~h}$.

- $\quad$ No tempo $0 \mathrm{~h}$ não temos diferença significativa entre os grupos.

- No tempo 6 horas além do G II ser diferente dos demais, temos que as médias dos G III e G IV são significativamente diferentes entre si.

- Nos tempos 12 h e 24 h, o grupo G II é significativamente diferente dos demais.

A Tabela 5.3 foi dividida em sub-tabelas para facilitar a comparação de cada grupo entre cada um dos tempos, e entre os grupos para cada um dos tempos (APÊNDICE C a APÊNDICE J). 
Fase 2 - Avaliação da sobrevivência celular

Na Tabela 5.4 temos as médias e desvios padrão para os percentuais, as quais também estão representadas no Gráfico 5.2. No momento inicial todas as amostras são propositalmente iguais a $1 \times 10^{3}$ células por placa.

Tabela 5.4 - Médias e desvios padrão (entre parênteses) para a contagem de células sobreviventes $\left(10^{3}\right)$ - longo prazo

\begin{tabular}{|c|c|c|c|c|c|}
\hline \multirow[b]{2}{*}{ Grupos } & \multicolumn{5}{|l|}{ Tempo } \\
\hline & 0 dias & 2 dias & 4 dias & 6 dias & 8 dias \\
\hline Controle-G I & $1(0,00)$ & $4,0(0,10)$ & $4,50(0,36)$ & $6,20(0,30)$ & $6,93(0,31)$ \\
\hline$G \|$ & $1(0,00)$ & $2,53(0,76)$ & $2,27(0,31)$ & $0,02(0,03)$ & $0,00(0,00)$ \\
\hline G III & $1(0,00)$ & $4,63(0,21)$ & $5,47(0,12)$ & $2,97(0,40)$ & $0,37(0,10)$ \\
\hline G IV & $1(0,00)$ & $3,90(0,10)$ & $4,63(0,47)$ & $5,50(0,92)$ & $4,90(0,46)$ \\
\hline
\end{tabular}

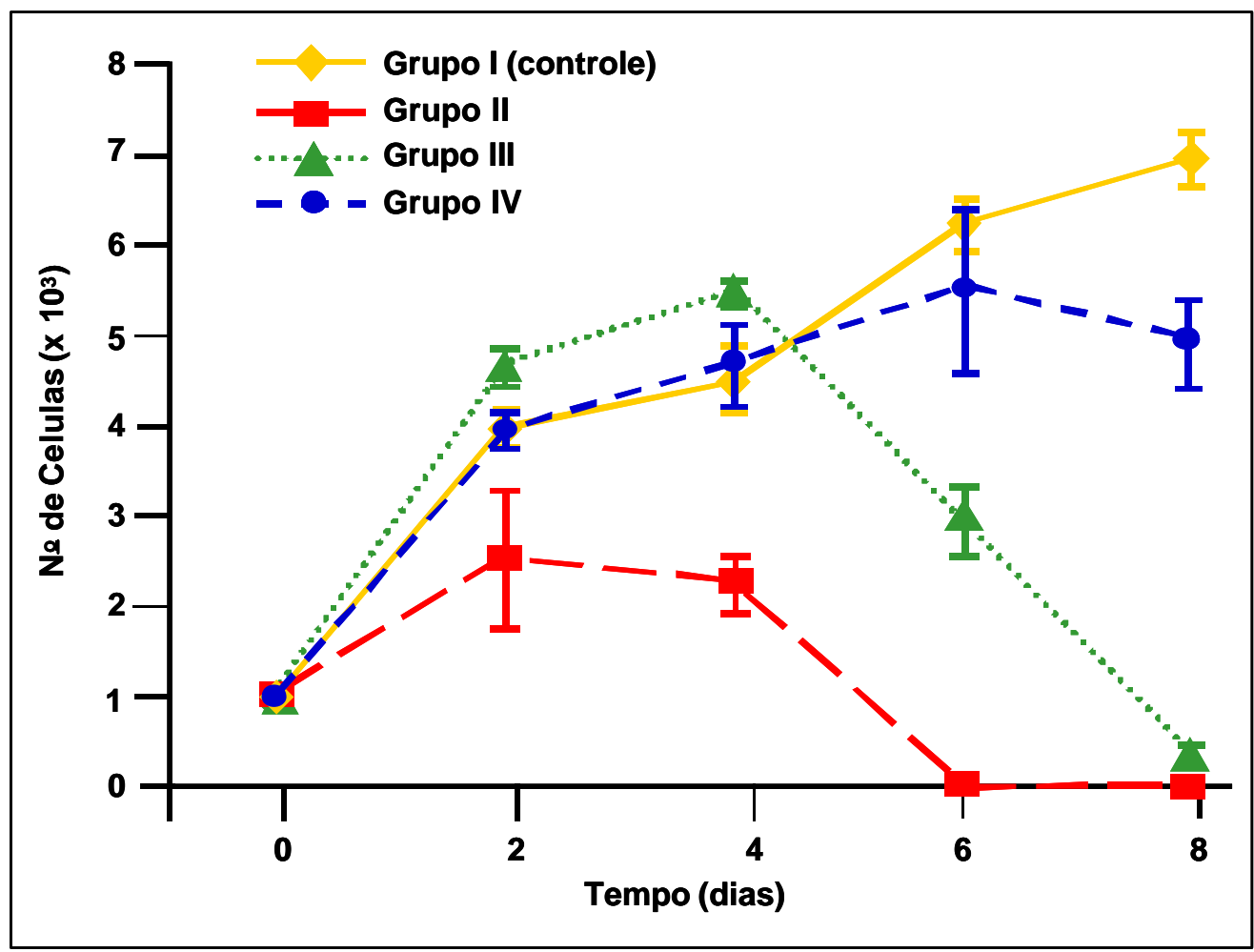

Gráfico 5.2. - Médias \pm 1 e desvios padrão para a contagem de células sobreviventes $\left(10^{3}\right)$ - longo prazo 
Por eles podemos observar que:

- Os grupos G I e G IV apresentam comportamento semelhante indicando sempre o crescimento da quantidade.

- Os grupos G II e G III são aparentemente semelhantes, com um aumento inicial seguido de queda, mas o grupo G II apresentou um menor crescimento e uma queda chegando a médias em torno de 0.

- Quanto às variabilidades temos que elas não são relativamente grandes sem grandes destaques.

$\mathrm{Na}$ Tabela 5.5 temos o resultado da ANOVA aonde temos que a coluna importante é a do nível descritivo e pela qual concluímos que existe interação significativa entre os grupos e o tempo, ou seja a diferença entre os grupos varia ao longo do tempo.

Tabela 5.5 - Análise de variância para percentual - Longo prazo

\begin{tabular}{|c|c|c|c|c|c|}
\hline $\begin{array}{ll}\text { Fonte } & \text { de } \\
\text { Variação } & \end{array}$ & $\begin{array}{l}\text { Graus de } \\
\text { liberdade }\end{array}$ & $\begin{array}{l}\text { Soma de } \\
\text { quadrados }\end{array}$ & $\begin{array}{l}\text { Quadrados } \\
\text { médios }\end{array}$ & $\begin{array}{l}\text { Estatística } \\
\mathrm{F}\end{array}$ & $\begin{array}{l}\text { Nível } \\
\text { descritivo }\end{array}$ \\
\hline Tempo & 3 & 0,08284 & 0,02761 & 17,64 & 0,000 \\
\hline Grupo & 3 & 1,23896 & 0,41299 & 263,78 & 0,000 \\
\hline Tempo * Grupo & 9 & 0,75605 & 0,08401 & 53,65 & 0,000 \\
\hline Resíduo & 32 & 0,05010 & 0,00157 & & \\
\hline Total & 47 & 2,12795 & & & \\
\hline
\end{tabular}

Para verificarmos qual grupo é diferente de qual, fizemos uma comparação múltipla pelo método de Tukey, pela qual comparamos todos os grupos dois a dois. Na Tabela 5.6 temos o resultado geral da análise. 


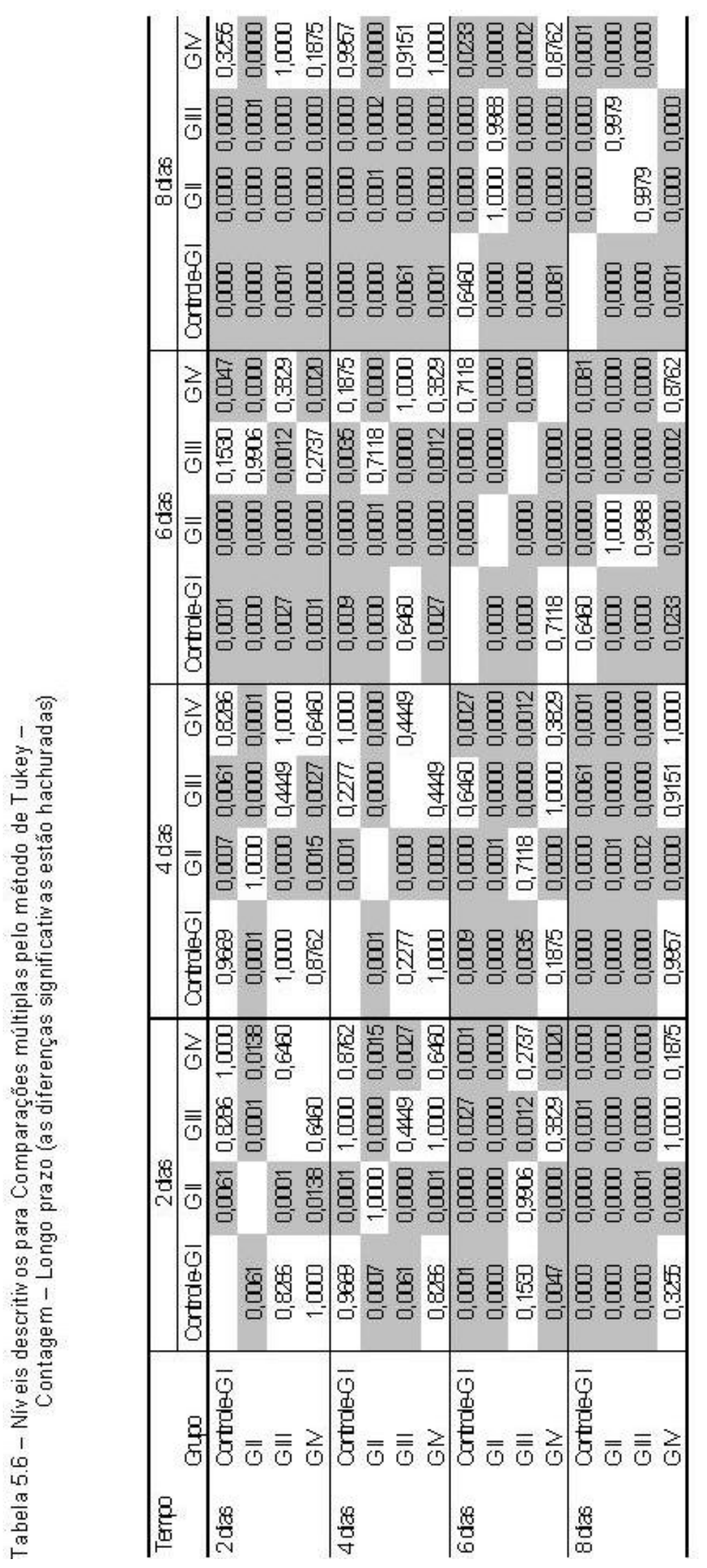


Pela tabela podemos observar que:

- Ao longo do tempo o grupo $\mathrm{G} \mathrm{I}$, temos que as médias em 2 e 4 dias são iguais entre si e as médias em 6 e 8 dias também são iguais entre si, mas significativamente diferentes das duas primeiras. $\mathrm{O}$ mesmo acontece com o G II.

- $\quad$ O grupo G III tem somente igualdade entre as médias dos dias 2 e 4.

- O grupo G IV somente apresenta diferença significativa entre as médias de 2 dias e de 6 dias.

- Nos dias 2 e 4 temos que as médias do grupo G II são significativamente diferentes das dos demais grupos.

- No tempo 6 dias além do grupo G II ser diferente dos demais, temos também que as médias do grupo G III são significativamente diferentes das dos demais grupos.

- No tempo 8 dias temos igualdade somente entre os grupos G II e G III.

Para facilitar dividimos a Tabela 5.6 em sub-tabelas onde podemos ver melhor a comparação ao longo de cada grupo e entre os grupos para cada um dos tempos (APÊNDICE K a APÊNDICE R). 


\section{DISCUSSÃO}

Muitas das injúrias traumáticas dentárias resultam em danos às estruturas pulpares e periodontais, como alterações da vitalidade, processos de mortificação pulpar, calcificações difusas e processos de reabsorções internas e externas, tendo a sua gravidade diretamente relacionada com a presença de contaminação pulpar ou periodontal (CAMARGO, 1998; LAGEMARQUES, 1998).

Por exemplo, nos quadros de avulsão dental, observa-se 0 rompimento do feixe vásculo-nervoso e severos danos às fibras do ligamento periodontal relacionados à secagem, compressão e remoção física dessas fibras.

A revista da literatura mostra que o tempo de permanência extraalveolar tem uma relação direta com o desenvolvimento de reabsorções substitutivas. Após um curto período de tempo, as células do ligamento periodontal começam a se degenerar em decorrência da desidratação, terminando por necrosar (ANDREASEN, 1981a; ANDREASEN; ANDREASEN, 1991; ANDREASEN et al. 1995a; DUGGAL; TOUMBA; PATERSON, 1994; SCHATZ; HAUSHERR; JOHO, 1995). O melhor prognóstico para um caso de avulsão relaciona-se com o reimplante imediato, mas nos casos onde há impossibilidade de se realizar o reimplante imediato, este deve ficar armazenado em um meio que permita a manutenção da vitalidade e viabilidade das células do ligamento periodontal. 
Frente às injúrias traumáticas dentárias mais severas, como a intrusão e a avulsão, instala-se uma resposta inflamatória que promove a reabsorção dos tecidos lesados. Esse processo reabsortivo está diretamente associado a uma resposta inflamatória no ligamento periodontal lesado, expondo a dentina e promovendo uma comunicação direta com a polpa através dos túbulos dentinários. O tratamento para as reabsorções inflamatórias relaciona-se com o controle da reação inflamatória inicial e a remoção do agente de manutenção desse processo.

Tendo conhecimento dos processos que desencadeiam e mantém a reabsorção, é possível determinar uma conduta clínica mais adequada associada ao uso de medicações que possam atingir a área lesada, na tentativa de bloquear ou até mesmo inibir o processo reabsortivo.

Para Vanderas (1993), a medicação intracanal ideal ainda não foi encontrada; neste rumo, inúmeras substâncias têm sido propostas para atingir este objetivo, pois a atuação da medicação intracanal nos tecidos adjacentes é de suma importância para o tratamento das reabsorções radiculares. Além disso, se faz necessário o correto preparo do canal através do uso de instrumentos e substâncias químicas que promovam o aumento da permeabilidade dentinária radicular, permitindo dessa forma a difusão da medicação até a superfície externa da raiz.

Uma vez controlada a contaminação existente e valendo-se de uma medicação que mantenha a sanificação obtida durante o preparo químicocirúrgico, espera-se que essa medicação seja bio-compatível e efetiva no combate do processo reabsortivo. 
Biocompatibilidade é a propriedade que um material apresenta no desempenho de suas funções diante da aceitação do mesmo pelos tecidos, que pode ser inicialmente testada em nível celular, ou seja, em testes de citotoxicidade. Neste sentido, testes de citotoxicidade empregando-se cultura de células têm sido utilizados nos campos da Odontologia, Medicina e Biologia com a possibilidade de se estudar os efeitos físicos e químicos de diversos materiais em células vivas (FRESHNEY, 1990).

O objetivo do presente trabalho foi avaliar a citotoxicidade do alendronato de sódio, in vitro, em cultura de células originadas de fibroblastos de ligamento periodontal humano, uma vez que, sendo células primárias, essas apresentam potencial metabólico mais próximo das condições in vivo.

A Federação Dentária Internacional (1980), publicou uma normativa nomeada de "Práticas estandardizadas recomendadas para avaliação biológica dos materiais dentários", cuja análise dos materiais devam ser realizadas seguindo-se uma ordenação segundo níveis biológicos, classificados em testes iniciais, testes secundários e testes de uso, sendo que a análise da citotoxicidade por meio de cultura de células constitui um dos testes iniciais.

Schwalz (1994), ressaltou que as células de linhagem permanente e as células derivadas de "explantes" são as mais aplicadas nos testes de toxicidade de materiais de uso odontológico, sendo que as primeiras são bem definidas, apresentam boa reprodutividade com sistemas simples de replicagem, mas sem o potencial metabólico específico das células quando 
in vivo. Já as células primárias (derivadas de "explantes"), apresentam um potencial metabólico mais próximo das condições in vivo. Por esse motivo, optamos por usar uma linhagem primária de fibroblastos de ligamento periodontal humano, pois são as células que constituem o principal tipo celular do ligamento periodontal, estando presentes tanto no ligamento normal quanto neste tecido inflamado.

Os testes de citotoxicidade de materiais odontológicos em cultura celular são ferramentas fundamentais para se compreender seus comportamentos biológicos, desde que a limitação do método seja considerada quando da interpretação dos resultados e que os experimentos desenvolvidos em cultura celular não substituam aqueles desenvolvidos em animais, mas que possam contribuir para a redução de seu número (SCHWALZ, 1994).

No que se refere ao processo de reabsorção, sabe-se que requer a remoção controlada dos componentes orgânicos e inorgânicos por células reabsortivas específicas, denominadas osteoclastos, formadas a partir da fusão de células mononucleares derivadas de precursores hematopoiéticos do baço e medula óssea (ANDREASEN; ANDREASEN, 1994; MARKS Jr, 1983). Para os autores Pierce e Lindskog (1989), Andreasen e Andreasen (1994), os dentinoclastos são morfologicamente similares aos osteoclastos e apresentam atividades enzimáticas semelhantes, produzindo lacunas de reabsorção na superfície dentinária e deslocando-se pelos sítios de reabsorção. 
Uma característica importante dos osteoclastos, ressaltada por Andreasen e Andreasen (1994), é a presença de uma área especializada na membrana plasmática, denominada de borda rugosa, que nada mais é do que um complexo sistema de pregas que se encontra adjacente á superfície de reabsorção óssea. A acidificação destas microvilosidades promove a dissolução da porção mineral, expondo assim a matriz orgânica à atividade enzimática proteolítica, além de estimular diretamente os mediadores da reabsorção osteoclástica.

A seleção dos fármacos utilizados na fase de medicação intracanal, nos casos de avulsão, baseia-se no fato que os processos reabsortivos mais severos, denominados reabsorções substitutivas, apresentam grandes dificuldades para o seu controle, fazendo com que estudos sejam conduzidos no sentido de se encontrar medicamentos que sejam realmente efetivos para esse fim. Diante desse fato, torna-se claro a necessidade de se desenvolver metodologias para avaliar a citotoxicidade de substâncias e fármacos empregados durante a terapia endodôntica.

Dos inúmeros trabalhos publicados na literatura médica, surgiu a idéia de que os bisfosfonatos pudessem ser utilizados como medicação intracanal, ou então por imersão do dente por um determinado período de tempo em soluções contendo bisfosfonato, para os casos de reimplante, pois são substâncias que reduzem o índice de dissolução da hidroxiapatita mineral do osso, impedindo assim a reabsorção óssea (SATO et al., 1991).

Os bisfosfonatos agem por meio da inibição da atividade de reabsorção dos osteoclastos, daí serem empregados como agentes 
terapêuticos em doenças ósseas hiper reabsortivas como a doença de Paget, hipercalcemia maligna ou ainda na osteoporose, mas o seu mecanismo de ação ainda não está totalmente esclarecido.

Dentre os bisfosfonatos, o alendronato de sódio é um dos mais potentes inibidores da atividade osteoclástica, pois em áreas de elevada atividade fisiológica, onde o metabolismo ósseo é maior, os bisfosfonatos se concentram de forma seletiva e após serem absorvidos se ligam à hidroxiapatita do osso exposto nos locais de reabsorção.

Sato et al. (1991), em pesquisas realizadas em ratos, propuseram um mecanismo de ação que é bem aceito, baseado no fato de que ao atingir concentrações entre 0,1 e $1 \mathrm{mM}$ na região da zona clara, o alendronato foi capaz de gerar um aumento de permeabilidade iônica na borda rugosa dos osteoclastos, promovendo dessa forma a inativação da célula.

Para Sahni et al. (1993), os achados conflitantes entre os estudos in vivo e in vitro sugerem que os bisfosfonatos não atuem somente através de ações diretas na atividade osteoclástica ou de recrutamento, mas também por outros mecanismos, uma vez que os bisfosfonatos afetam outras células envolvidas na reposição óssea, incluindo osteoblastos e macrófagos, dos quais tanto a atividade quanto à proliferação são inibidas in vitro.

Estudos realizados por Giavaresi et al. (2001), Hernandez et al. (2001), Meraw e Reeve (1999) e Nishikawa et al. (1996), confirmam que os bisfosfonatos inibem a reabsorção óssea pelo controle direto da ativação dos osteoclastos e controle indireto da função pela diminuição dos fatores 
ativadores de osteoclastos, favorecendo assim o aumento da densidade mineral óssea.

A primeira investigação sobre a possível utilização dos bisfosfonatos no traumatismo dental foi realizada por Liewehr et al. em 1995, onde os autores estudaram in vitro a capacidade de fatias de dentina imersas em dois tipos de bisfosfonatos, em resistir à atividade de dentinoclastos. Os achados evidenciaram que os bisfosfonatos foram capazes de reduzir o processo de reabsorção de dentina mediada por dentinoclastos in vitro.

Outro estudo in vitro realizado por Sommercorn et al. (2000), também avaliou o efeito do alendronato na neoformação de dentina em dentes humanos com ápices imaturos. Os resultados mostraram que o grupo tratado com alendronato obteve mais crescimento na região apical que 0 grupo controle, e que o crescimento na região apical foi significantemente maior que nas outras áreas de mensuração para ambos os grupos controle e alendronato.

Corroborando com os resultados acima, Levin et al. (2001), em um estudo sobre o efeito da aplicação tópica de Alendronato em dentes de cães reimplantados secos, os dados evidenciaram que as raízes embebidas no bisfosfonato tiveram uma reparação estatisticamente mais significante do que nos demais grupos, confirmando que a lógica da avulsão dental e do reimplante, permite a administração tópica de drogas na superfície radicular. Inúmeras pesquisas têm demonstrado que o efeito dos bisfosfonatos também é dependente de sua concentração, justificando a realização de um experimento para que se determinem quais concentrações poderiam ser 
efetivas em um futuro estudo biológico in vivo. Sustenta-se então a necessidade de realizar um estudo que avalie a citotoxicidade do alendronato de sódio em diferentes concentrações e em cultura de fibroblastos de ligamento periodontal humano.

De fato a literatura não relata nenhuma pesquisa sobre os efeitos desse fármaco sobre essas células, as primeiras afetadas frente ao quadro de reabsorções substitutivas, muitas vezes inviabilizando a reparação do sistema osso, periodonto e cemento radicular.

Em nosso experimento, utilizamos três diferentes concentrações do alendronato de sódio: $10^{-5}, 10^{-6}$ e $10^{-7} \mathrm{M}$, conforme resultados observados no estudo piloto em que concentrações maiores que $10^{-5} \mathrm{M}$, demonstraram-se extremamente citotóxicas, embora os resultados obtidos por Kum et al. (2003), que nas mesmas concentrações aplicadas em cultura de osteoclastos, não evidenciou nenhum efeito citotóxico.

Os resultados do nosso experimento revelaram uma citotoxicidade diretamente proporcional à sua concentração e crescimento celular progressivo e similar ao grupo controle a partir da concentração $10^{-6} \mathrm{M}$, fato esse que corrobora os achados de Sommercorn et al. (2000), que verificaram que a concentração de $10^{-9} \mathrm{M}$ não apresentou citotoxicidade e foi efetiva na aceleração de formação dentinária in vitro.

Outros trabalhos, realizados in vitro, demonstraram resultados ora semelhantes, ora conflitantes, mesmo com outros tipos de células, como, por exemplo, as avaliações realizadas por Liewhr et al. (1995) e Garcia-Moreno et al. (1998), que analisaram a viabilidade de osteoclastos e osteoblastos em 
seus respectivos trabalhos. O primeiro obteve diminuição significativa de reabsorção dentinária empregando concentrações de $10^{-5} \mathrm{M}$ e $10^{-6} \mathrm{M}$ de dois bisfosfonatos, enquanto que, os resultados do segundo autor, evidenciaram que as concentrações maiores ou igual a $10^{-4} \mathrm{~mol} / \mathrm{L}$ de alendronato, mostraram que nenhuma célula viável foi observada nas culturas com concentrações maiores ou igual a $10^{-3} \mathrm{~mol} / \mathrm{L}$, conclusão essa também verificada e confirmada em nosso experimento.

A pesquisa realizada por Katayama (2004), avaliou a citotoxicidade do alendronato de sódio sobre cultura celular em endoteliócitos. As concentrações utilizadas no experimento in vitro, foram as mesmas do nosso experimento, mas os resultados mostraram ser citotóxicos em todas as concentrações utilizadas.

Uma outra pesquisa de resultado conflitante quando comparado com o nosso, foi a de Lima (2004), que avaliou o efeito do alendronato de sódio na forma de gel, em cultura celular de ligamento periodontal humano, desenvolvidas sobre fragmentos de dentina radicular. Os resultados evidenciaram que o crescimento celular se tornou estável depois de 3 dias de cultura, mas foram significantemente menores em comparação com o grupo controle.

Ao revisar a literatura pudemos observar que trabalhos científicos como os de Weinreb et al. (1994), Reddy et al. (1995) e Yaffe et al. (1997), concordam que o uso sistêmico de bisfosfonatos tem demonstrado efeitos benéficos na proteção da reabsorção osteoclástica causada tanto por periodontites quanto nos casos onde procedimentos de retalhos muco- 
periostais são indicados, quando comparado com placebos, e que promove uma proteção prolongada após o término da administração da droga.

Além desses estudos, outras avaliações suportam a hipótese de que após a sua administração, o alendronato adere à superfície de hidroxiapatita exposta, podendo a acidificação causar sua liberação dentro da zona clara, interferindo com a função da borda pregueada da membrana e, por conseqüência, inibindo a reabsorção.

Diante dos resultados observados, em nossa avaliação metodológica, das análises de outras pesquisas e de algumas opiniões conflitantes encontradas na revista da literatura, achamos lícito afirmar que esses resultados sugeririam que a administração local, isto é, tanto usando o canal radicular de um dente avulsionado e reimplantado como um reservatório da medicação, permitindo a sua difusão pelos túbulos dentinários à superfície externa da raiz, ou imergindo a raiz por um período de tempo nessa mesma medicação, poderia ser um tratamento efetivo para a prevenção da reabsorção substitutiva.

Tal fato nos permite afirmar que novos estudos deverão ser realizados no sentido de verificar outras concentrações, para futuros testes em animais e quem sabe em humanos para fechar a lacuna existente no tratamento e controle das reabsorções substitutivas. 


\section{CONCLUSÕES}

Com base na literatura consultada e nos resultados obtidos, parece lícito concluir que:

7.1 O Alendronato de sódio, em contato direto com fibroblastos de ligamento periodontal humano em cultura, se mostrou citotóxico nas concentrações mais elevadas $\left(10^{-5}\right.$ e $\left.10^{-6} \mathrm{M}\right)$.

7.2 A concentração de $10^{-7} \mathrm{M}$, teve um comportamento semelhante ao grupo controle nas células testadas. 


\section{REFERÊNCIAS ${ }^{1}$}

Adachi $\mathrm{H}$, Igarashi $\mathrm{K}$, Mitani $\mathrm{H}$, Shinoda $\mathrm{H}$. Effects of topical administration of a bisphosphonate (risedronate) on orthodontic tooth movements in rats. $J$ Dent Res 1994;73(8):1478-84.

Adami S, Mian M, Gatti P, Rossini M, Zamberlan N, Bertoldo F, et al. Effects of two oral doses of alendronate in the treatment of Paget's disease of bone. Bone 1994;15(4):415-7.

Andreasen JO. Effect on extra-alveolar period and storage media upon periodontal and pulpal healing after replantation of mature permanent incisors in monkeys. Int J Oral Surg 1981a;10(1):43-53.

Andreasen JO. The effect of pulp extirpation or root canal treatment on periodontal healing after replantation of permanent incisors in monkeys. $J$ Endod 1981b;7(6):245-52.

Andreasen JO. Periodontal healing after replantation and autotransplantation of incisors in monkeys. Int J Oral Surg 1981c;10(1):5461.

Andreasen JO, Andreasen FM. Traumatismo dentário e soluções clínicas. São Paulo: Panamericana; 1991. 166 p.

Andreasen JO, Andreasen FM. Texto e atlas colorido de traumatismo dental. Porto Alegre: Artmed Editora; 2001. 770 p.

Andreasen JO, Andreasen FO. Text book and color atlas of traumatic injuries to the teeth.Copenhagen: Munksgaard International; 1994.753 p.

Andreasen JO, Hjorting-Hansen E. Replantation of teeth. Radiographic and clinical study of 110 human teeth replanted after acidental loss. Acta Odontol Scand 1966;24(3):263-86.

${ }^{1}$ De acordo com estilo Vancouver. Abreviatura de periódicos segundo Bases de Dados MEDLINE 
Andreasen JO, Borum MK, Jacobsen HL, Andreasen FM. Replantation of 400 permanent incisors. 2 Factors related to pulpal healing. Endod Dent Traumatol 1995a;11(2):59-68.

Andreasen JO, Borum MK, Jacobsen HL, Andreasen FM. Replantation of 400 permanent incisors. 4 Factors related to periodontal ligament healing. Endod Dent Traumatol 1995b;11(2):76-89.

Andreasen FM, Vestergaard Pedersen B. Prognosis of luxated permanent teeth. The development of pulp necrosis. Endod Dent Traumatol 1985;1(6):207-20.

Azria M. The calcitonins, physiology and pharmacology. Switzerland: Karger; 1989. $152 \mathrm{p}$.

Barret EJ, Kenny DJ. Avulsed permanent teeth: a review of the literature and treatment guidelines. Endod Dent Traumatol 1997;13(4):153-63.

Blomlöf L, Lindskog S, Hammarström L. Periodontal healing of exarticulated monkeys teeth stored in milk or saliva. Scand J Dent Res 1981;89(2):251-9.

Bombana AC. Reação inflamatória do olho de coelho que se segue à instalação de alguns fármacos de uso endodôntico. Rev Assoc Paul Cir Dent 1974;28(4):216-23.

Brunsvold M, Chaves ES, Kornman KS, Aufdemorte TB, Wood R. Effects of a bisphosphonate on experimental periodontites in monkeys. J Periodontol 1992;63(10):825-30.

Budavari S, O' Neil MJ, Smith A, Heckelman PE, Kineary JF. The Merck Index. New Jersey: Merck Research Laboratories; 1996. 2535 p.

Caldeira CL..Protocolo de atendimento:Dentes traumatizados.cap.15:Avulsões. Disponível em:URL:http://www.fo.usp.br/cade/manualtrauma.pdf[2004Out02] 
Camargo SCC. Avaliação in vitro da difusão da calcitonina sintética de salmão através da dentina radicular quando utilizada como medicação intracanal. Dissertação[Mestrado em Endodontia]. São Paulo: Faculdade de Odontologia da USP; 1998.

Chambers TJ. The pathobiology of the osteoclast. J Clin Pathol 1985;38(3):241-52.

Duggal MS, Toumba KJ, Paterson SA. Replantation of avulsed permanent teeth with avital periodontal ligaments:case report. Endodon Dent Traumatol 1994;10(6):282-5.

Federation Dentaire International. Recommended standard practices for biological evaluation of dental materials. Int Dent J 1980;30(2):140-88.

Filippi A, Pohl Y, Von Arx T. Treatment of replacement resorption with Endogain $^{\circledR}$ - a prospective clinical study. Dent Traumatol 2002;18(3):138-43.

Fleisch H. New bisphosphonate in osteoporosis. Osteoporos Int 1993;3 sppl. $2: 15-22$.

Flores MT, Andreasen JO, Bakland LK, Feiglin B, GutMann JL, Oikarinen K, et al. Guideline for the evaluation and management of traumatic dental injuries. Dent Traumatol 2001;17(5):193-8.

Fogelman I. The effects of oestrogen deficiency on the skeleton and its prevention. Br J Obstet Gynaecol 1996;103(14):5-9.

Foster $\mathrm{KH}$, Kulild JC, Weller N. Effect of smear layer removal on the diffusion of calcium hydroxide trough radicular dentin. J Endod 1993;19(3):136-40.

Freshney RI. Culture of animal cells. A manual of basic technique. New York: Wiley-Liss; 2000. 577 p.

Frost $\mathrm{MH}$. The biology of fracture healing: an overview for clinicians. Part I. Clin Orthop 1989;248:283-93. 
Garcia Moreno C, Serrano S, Nacher M, Diez A, Marinoso M L, Carbonell J et al. Effect of alendronate on cultured normal human osteoblasts. Bone 1998;22(3):233-9.

Geddes AD, D'Souza SM, Ebetino FH, Ibbotson KJ. Bisphosphonates: structure-activity relationships and therapeutic implications. In : Heersche JNM, Kanis JA, eds. Bone Mineral Res 1994:265-74.

Giavaresi G, Fini F, Gnudi S, Nicoli Aldini N, Rocca M, Carpi A, et al. Comparison of calcitonin, alendronate and fluorphosphate effect on ovariectomized rat bone. Biomed Pharmacother 2001;55:397-403.

Guedes-Pinto AC, Issáo M. Traumatismos em dentes anteriores. São Paulo: Artes Médicas; 1993. cap. 11, p. 213-35.

Hammarström L. Enamel matrix, cementum development and regeneration. J Clin Periodontol 1997;24(9):658-68.

Hammarström L, Blömof L, Feiglin B, Anderson I, Hedströn K-G, Lindskog S. Replantation of teeth and antibiotic treatment. Endod Dent Traumatol 1986; 2:51-7.

Hammarström L, Blömof L, Feiglin B, Lindskog S. Effect of calcium Hydroxide treatment on periodontal repair and root resorption. Endod Dent Traumatol 1986;2(5):184-9.

Harris ST, Gertz BJ, Genant HK, Eyre DR, Survill TT, Ventura JN, et al. The effect of short term treatment with alendronate on vertebral density and biochemical markers of bone remodeling in early postmenopausal women. $\mathrm{J}$ Clin Endocrinol Metab 1993;76(6):1399-406.

Hernandez CJ, Beaupré GS, Marcus R, Carter DR. A theorical analysis of the contributions of remodeling space, mineralization and bone balance to changes in bone mineral density during alendronate treatment. Bone 2001;29(6):511-6.

Huang SC, Remeikis NA, Daniel JC. Effects of long term exposure of human periodontal ligament cells to milk and other solutions. J Endodon 1996;22(1):30-3. 
Igarashi $\mathrm{K}$, Adachi $\mathrm{H}$, Mitani $\mathrm{H}$, Shinoda $\mathrm{H}$. Inhibitory effect of the topical administration of a bisphosphonate (risedronate) on root resorption incident to orthodontic tooth movement in rats. J Dent Res 1996;75(9):1644-49. Igarashi K, Mitani $\mathrm{H}$, Adachi $\mathrm{H}$, Shinoda $\mathrm{H}$. Anchorage and retentive effects of a bisphosphonate (AHBuBP) on tooth movements in rats. Am J Orthod Dentofacial Ortop 1994;106(3):279-89.

Kanis JA, Gertz BJ, Singer F, Ortolani S. Rationale for the use of alendronate in osteoporosis. Osteoporosis Int 1995;5(1):1-13.

Katayama MSM. Análise da citotoxidade do Alendronato de sódio em polietilenoglicol sobre cultura de endoteliócitos e no subcutâneo de ratos Dissertação [Mestrado em Endodontia]. São Paulo: Faculdade de Odontologia da USP; 2004.

Konnis AB. Treatment of traumatic tooth avulsion. NY State Dent $\mathrm{J}$ 1995;61(7):39-41.

Kum KY, Park JH, Yoo YJ, Choi BK, Lee HJ, Lee SJ. The Inhibitory effect of alendronate and Taurine on osteoclast differentiation mediated by Prophyromonas gingivalis sonicates in vitro. J Endod 2003;29(1):28-30.

Lage-Marques JL. Tratamento do traumatismo dental: conceito atual. In: Gonçalves EAN, Feller C. Atualização na clínica odontológica. São Paulo: APCD Artes Médicas; 1998. cap. 9, p. 201-15.

Lage-Marques JL, Salazar Silva JR, Prokopowitsch I. Traumatismo dental: avulsión, nuevos conceptos. Fola Oral 1995;1(2):68-72.

Levin L, Bryson EC, Caplan D, Trope M. Effect of topical alendronate on root resorption of dried replanted dog teeth. Dent Traumatol 2001;17(3):120-6.

Liberman UA, Weiss SR, Broll J, Minne HW, Quan H, Bell NH, et al. Effect of oral alendronate on bone mineral density and the incidence of fractures in postmenopausal osteoporosis. N Engl J Med 1995;333(22):1437-43.

Liewehr FR, Craft DW, Primack PD, Kulild JC, Turgeon DK, Sutherland DE, et al. Effect of bisphosphonates and gallium on dentin resorption in vitro. Endod Dent Traumatol 1995;11(1):20-6. 
Lima DBGO. Biocompatibilidade de superfícies radiculares comprometidas periodontalmente e tratadas com gel de alendronato. Dissertação[Mestrado em Periodontia]. São Paulo: Faculdade de Odontologia da USP;2004.

Lindskog S, Pierse A, Blömof L, Hammarström L. The role of the necrotic periodontal membrane in cementum resorption and ankylosis. Endod Dent Traumatol 1985;1:96-101.

Line SE, Polson AM, Zander HA. Relationship between periodontal injury, selective cell repopulation and ankylosis. J Periodontol 1974;45(10):725-30.

Marks Jr SC. The origin of osteoclasts: evidence, clinical implications and investigation challenges of an extraesqueletal source. J Oral Pathol 1983;12(4):226-56.

Martindale.The complete drug reference. London: Pharmaceutical Press; 2002. v. I. p.747-9.

Melo LL. Traumatismo Alveolo-Dentário. São Paulo: Artes Médicas; 1998. Série EAP-APCD (9),cap. 4, p. 127-53.

Meraw S, Reeve CM. Qualitative analysis of peripheral peri-implant bone and influence of alendronate sodium on early bone regeneration. $J$ Periodontol 1999;70(10):1228-33.

Nishikawa M, Akatsu T, Katayama Y, Yasutomo Y, Kado S, Kugai N, et al. Bisphosphonates act on osteoblastic cells and inhibit osteoclast formation in mouse marrow cultures. Bone 1996;18(1):9-14.

Oikarien K, Gundlach KKH, Pfeifer G. Late complications of luxated injuries to teeth. Endodon Dent Traumatol 1987;3:296-303.

Paiva JG, Antoniazzi JH. Conduta endodôntica diante de lesões traumáticas em dentes permanentes jovens. São Paulo: Artes Médicas;

1988. cap. 31, p. 727-57.

Paiva JG, Antoniazzi JH. Endodontia-Bases para a prática clínica. São Paulo: Artes Médicas; 1993. 886 p. 
Patel S. Current potential future drug treatments for osteoporosis. Ann Rheum Dis 1996;55(10):700-14.

Pierce A. Experimental basis for the management of dental resorption. Endod Dent Traumatol 1989;5(6):255-65.

Pierce A, Berg JO, Lindskog S. calcitonina as an alternative therapy in the treatment of root resorption. J Endod 1988;14(9):459-64.

Pierce A, Lindskog S. The effect of na antibiotic/corticosteroid paste on inflamatory root resorption in vivo. Oral Surg Oral Med Oral Phatol 1987;64(2):216-20.

Pierce A, Lindskog S. Early responses by osteoclasts in vivo and dentinoclasts in vitro to corticosteroids. J Submicros Cytol Pathol 1989;21(3):501-8.

Porras AG, Holland SD, Gertz BI. Pharmacokinetics of alendronate. Clin Pharmacokinet 1999;36(5):315-28.

Prokopowitsch I, Andrade W B. Uso da calcitonina no controle da reabsorção radicular externa substitutiva: a avaliação de 69 dentes tratados. In: Anais do World Congress on Dental Trauma; Guarujá, 1997. São Paulo: World Congress on Dental Trauma; 1997. p. 167.

Prokopowitsch I, Lage-Marques JL, Santos M, Davidowics H, Di Girolano Neto J, Carvalho VGP. Análise comparativa de algumas soluções armazenadoras usadas para estocagem de dentes de cães submetidos a avulsão dental e posterior reimplante. Uma Avaliação radiográfica. In: Anais da Reunião da Sociedade Brasileira de Pesquisa Odontológica; 1990 . São Paulo: SBPqO, 1990. p. 127.

Reddy MS, Weatherford TW, Anne Smith C, West BD, Jeffcoat MK, Jacks T $M$. Alendronate treatment of naturally-occurring periodontites in beagle dogs. J Periodontol 1995;66(3):211-7.

Rodan GA. Mechanism of action of Bisphosphonates. Annu Rev Pharmacol Toxicol 1998;38:375-88. 
Saag KG, Emkey R, Schnitzer TJ, Brown JP, Hawkins F, Goemaere S, et al. Alendronate for the prevention and treatment of glucocorticoid-induced osteoporosis. N Engl J Med 1998;339(5):292-9.

Sahni M, Guenther HL, Fleisch H, Collin P, Martin TJ. Bisphosphonates act on rat bone resorption through the mediation of osteoblasts. J Clin Invest 1993;91:2004-11.

Sato M, Grasser W, Endo N, Akins R, Simmons H, Thompson DD.

Bisphosphonate Action. Alendronate localization in rat bone and effects on osteoclast ultrastructure. J Clin Invest 1991;88(6):2095-105.

Schatz JP, Hausherr C, Joho JP. A retrospective clinical and radiologic study of teeth re-implanted following traumatic avulsion. Endodon Dent Traumatol 1995;11(5):235-9.

Schmidt LJ, Rowe DJ. The effects of disphosphonates on alveolar bone loss. Quintessence Int 1987;18(7):497-501.

Schwalz G. Use of cell cultures for toxicity testing of dental materials : advantages and limitations. J Dent 1994;22(12):S6-S11.

Shulman LB, Gedalia I, Feingold RM. Fluoride concentration in root surfaces and alveolar bone of fluoride-immersed monkeys incisors three weeks after replantation. J Dent Res 1973;52(6):1314-6.

Soares I, Felippe MC, Lucena M. Tratamento de dentes com rizogênese incompleta. Rev ABO Nac 1996;4(1):26-31.

Söder PO, Otteskog P, Andreasen J, Modéer T. Effect of drying on viability of periodontal membrane. Scand Dent J Res 1977;85(3):164-8.

Sommercorn LM, Di Fiore PM, Dixit S N, Koerber A, Lingen MW, Veis A. Effect of alendronate on immature human dental root explants. J Endod 2000;26(3):133-7.

Tancredo N. Procedimentos clínicos na avulsão dentária. Rev Bras Odontol 1987;64(1):26-35. 
Trope M. Clinical managment of the avulsed tooth. Dent Clin North Amer 1995;39(1):221-5.

Trope M. Root resorption of dental traumatic origin : classification based on etiology. Pract Periodont Aesthet Dent 1998;10(4):515-22.

Trope M, Yesilsoy C, Koren L, Moshonov J, Friedman S. Effects of different endodontic treatment protocols on periodontal repair and root resorption of replanted dog teeth. J Endodn 1992;18(10):492-6.

Vaes G. Cellular biology and biochemical machanism of bone resorption. A review of recent developments on the formation, activation and mode of action of osteoclasts. Clin Orthop 1988;231:239-71.

Vanderas AP. Effects of intracanal medications on inflammatory resorption or occurrence of ankilosis in mature traumatized teeth: a review. Endod Dent Traumatol 1993;6:175-184.

Weinreb M, Quartuccio H, Seedor JG, Aufdemorte TB, Brunsvold M, Chaves E, et al. J Periodont Res 1994;29(1):35-40.

Wiebkin OW, Cardaci SC, Heithersay GS, Pierce AM. Therapeutic delivery of calcitonina to inhibit external inflammatory root resorption. Diffusion Kinetics of calcitonina through the dental root. Endod Dent Traumatol 1996;12(6):265-71.

Yaffe A, Iztkovich M, Earon Y, Alt I, Lilov R, Binderman I. Local delivery of an amino bisphosphonate prevents the resorptive phase of alveolar bone following mucoperiosteal flap surgery in rats. J Periodontol 1997;68(9):884-9. 
APÊNDICE A - Valores originais correspondentes à percentagem de viabilidade celular(\%), distribuídos de acordo com os tempos experimentais obtidos com os experimentos de curto prazo contendo meio condicionado

\begin{tabular}{l|cccc}
\hline \multirow{2}{*}{ Grupos } & \multicolumn{4}{|c}{ Tempo } \\
\cline { 2 - 5 } Controle-G I & Oh & $6 \mathrm{~h}$ & $12 \mathrm{~h}$ & $24 \mathrm{~h}$ \\
\hline \multirow{3}{*}{ G II } & 91 & 91.8 & 96.5 & 92.9 \\
& 93.1 & 90.4 & 89.9 & 90.7 \\
& 93.5 & 90.3 & 91.1 & 92.1 \\
\hline \multirow{3}{*}{ G III } & 98.7 & 73.9 & 61.7 & 63.3 \\
& 92.7 & 81.6 & 63.1 & 63.5 \\
& 94.1 & 69.8 & 61.7 & 62.5 \\
\hline \multirow{3}{*}{ G IV } & 93.6 & 92.1 & 87.4 & 84.6 \\
& 90.7 & 82.8 & 85.7 & 85.8 \\
& 89.9 & 85.1 & 90 & 87.2 \\
\hline
\end{tabular}


APÊNDICE B - Valores originais $\left(\mathrm{n} \times 10^{4}\right)$ correspondentes à viabilidade celular, distribuídos de acordo com os tempos experimentais obtidos com os experimentos de longo prazo contendo meio condicionado

\begin{tabular}{l|ccccc}
\hline \multirow{3}{*}{ Grupos } & \multicolumn{5}{c}{ Tempo } \\
\cline { 2 - 6 } Controle-G I & Oh & 2 Dias & 4 Dias & 6 Dias & 8 Dias \\
\hline \multirow{3}{*}{ G II } & 0.10 & 0.40 & 0.41 & 0.62 & 0.72 \\
& 0.10 & 0.39 & 0.46 & 0.65 & 0.70 \\
& 0.10 & 0.41 & 0.48 & 0.59 & 0.66 \\
\hline \multirow{3}{*}{ III } & 0.10 & 0.20 & 0.22 & 0.0 & 0.0 \\
& 0.10 & 0.22 & 0.20 & 0.0 & 0.0 \\
& 0.10 & 0.34 & 0.26 & 0.006 & 0.0 \\
\hline \multirow{3}{*}{ G IV } & 0.10 & 0.44 & 0.56 & 0.26 & 0.046 \\
& 0.10 & 0.47 & 0.54 & 0.34 & 0.040 \\
& 0.10 & 0.48 & 0.54 & 0.29 & 0.026 \\
\hline
\end{tabular}


APÊNDICE C - Níveis descritivos para Comparações múltiplas pelo método de Tukey Percentual - Curto prazo - G I ao longo do tempo (as diferenças significativas estão hachuradas)

\begin{tabular}{l|llll}
\hline & Oh & $6 \mathrm{~h}$ & $12 \mathrm{~h}$ & $24 \mathrm{~h}$ \\
\hline Oh & & 1,0000 & 1,0000 & 1,0000 \\
$6 \mathrm{~h}$ & 1,0000 & & 1,0000 & 1,0000 \\
$12 \mathrm{~h}$ & 1,0000 & 1,0000 & & 1,0000 \\
$24 \mathrm{~h}$ & 1,0000 & 1,0000 & 1,0000 & \\
\hline
\end{tabular}

APÊNDICE D - Níveis descritivos para Comparações múltiplas pelo método de Tukey Percentual - Curto prazo - G II ao longo do tempo (as diferenças significativas estão hachuradas)

\begin{tabular}{l|llll}
\hline & $0 h$ & $6 h$ & $12 h$ & $24 h$ \\
\hline Oh & & 0,0000 & 0,0000 & 0,0000 \\
$6 h$ & 0,0000 & & 0,0003 & 0,0010 \\
$12 h$ & 0,0000 & 0,0003 & & 1,0000 \\
$24 h$ & 0,0000 & 0,0010 & 1,0000 & \\
\hline
\end{tabular}

APÊNDICE E - Níveis descritivos para Comparações múltiplas pelo método de Tukey Percentual - Curto prazo - G III ao longo do tempo (as diferenças significativas estão hachuradas)

\begin{tabular}{l|llll}
\hline & $0 h$ & $6 h$ & $12 h$ & $24 h$ \\
\hline Oh & & 0,7751 & 0,9545 & 0,5549 \\
$6 h$ & 0,7751 & & 1,0000 & 1,0000 \\
$12 h$ & 0,9545 & 1,0000 & & 1,0000 \\
$24 h$ & 0,5549 & 1,0000 & 1,0000 & \\
\hline
\end{tabular}

APÊNDICE F - Níveis descritivos para Comparações múltiplas pelo método de Tukey Percentual - Curto prazo - G IV ao longo do tempo (as diferenças significativas estão hachuradas)

\begin{tabular}{l|llll}
\hline & $0 h$ & $6 h$ & $12 h$ & $24 h$ \\
\hline Oh & & 0,9995 & 0,8221 & 1,0000 \\
$6 h$ & 0,9995 & & 0,2290 & 1,0000 \\
$12 h$ & 0,8221 & 0,2290 & & 0,6122 \\
$24 h$ & 1,0000 & 1,0000 & 0,6122 & \\
\hline
\end{tabular}


APÊNDICE G - Níveis descritivos para Comparações múltiplas pelo método de Tukey Percentual - Curto prazo - grupos no momento Oh (as diferenças significativas estão hachuradas)

\begin{tabular}{l|llll}
\hline & Controle- & & \\
Grupo & G I & G II & G III & G IV \\
\hline Controle-G I & & 0,9981 & 1,0000 & 1,0000 \\
G II & 0,9981 & & 0,9479 & 0,9999 \\
G III & 1,0000 & 0,9479 & & 1,0000 \\
G IV & 1,0000 & 0,9999 & 1,0000 & \\
\hline
\end{tabular}

APÊNDICE H - Níveis descritivos para Comparações múltiplas pelo método de Tukey Percentual - Curto prazo - grupos no momento 6h (as diferenças significativas estão hachuradas)

\begin{tabular}{|c|c|c|c|c|}
\hline Grupo & $\begin{array}{l}\text { Controle } \\
\text { G I }\end{array}$ & $G \|$ & G III & G IV \\
\hline Controle-G I & & 0,0001 & 0,8937 & $\overline{0,8146}$ \\
\hline$G \|$ & 0,0001 & & 0,0016 & 0,0000 \\
\hline G III & 0,8937 & 0,0016 & & 0,0401 \\
\hline G IV & 0,8146 & 0,0000 & 0,0401 & \\
\hline
\end{tabular}

APÊNDICE I -Níveis descritivos para Comparações múltiplas pelo método de Tukey Percentual - Curto prazo - grupos no momento 12h (as diferenças significativas estão hachuradas)

\begin{tabular}{l|llll}
\hline Grupo & \multicolumn{2}{|l}{ Controle- } & & \\
G I & G II & G III & G IV \\
\hline Controle-G I & & 0,0000 & 0,7584 & 0,9239 \\
G II & 0,0000 & & 0,0000 & 0,0000 \\
G III & 0,7584 & 0,0000 & & 1,0000 \\
G IV & 0,9239 & 0,0000 & 1,0000 & \\
\hline
\end{tabular}

APÊNDICE J - Níveis descritivos para Comparações múltiplas pelo método de Tukey Percentual - Curto prazo - grupos no momento 24h (as diferenças significativas estão hachuradas)

\begin{tabular}{l|llll}
\hline Grupo & Controle- & & & \\
G I & G II & G III & G IV \\
\hline Controle-G I & & 0,0000 & 0,4163 & 0,9999 \\
G II & 0,0000 & & 0,0000 & 0,0000 \\
G III & 0,4163 & 0,0000 & & 0,0839 \\
G IV & 0,9999 & 0,0000 & 0,0839 & \\
\hline
\end{tabular}


APÊNDICE K - Níveis descritivos para Comparações múltiplas pelo método de Tukey Contagem - Longo prazo - G I ao longo do tempo (as diferenças significativas estão hachuradas)

\begin{tabular}{l|llll}
\hline & 2 dias & 4 dias & 6 dias & 8 dias \\
\hline 2 dias & & 0,9669 & 0,0001 & 0,0000 \\
4 dias & 0,9669 & & 0,0009 & 0,0000 \\
6 dias & 0,0001 & 0,0009 & & 0,6460 \\
8 dias & 0,0000 & 0,0000 & 0,6460 & \\
\hline
\end{tabular}

APÊNDICE L - Níveis descritivos para Comparações múltiplas pelo método de Tukey Contagem - Longo prazo - G II ao longo do tempo (as diferenças significativas estão hachuradas)

\begin{tabular}{l|llll}
\hline & 2 dias & 4 dias & 6 dias & 8 dias \\
\hline 2 dias & & 1,0000 & 0,0000 & 0,0000 \\
4 dias & 1,0000 & & 0,0001 & 0,0001 \\
6 dias & 0,0000 & 0,0001 & & 1,0000 \\
8 dias & 0,0000 & 0,0001 & 1,0000 & \\
\hline
\end{tabular}

APÊNDICE M - Níveis descritivos para Comparações múltiplas pelo método de Tukey Contagem - Longo prazo - G III ao longo do tempo (as diferenças significativas estão hachuradas)

\begin{tabular}{l|llll}
\hline & 2 dias & 4 dias & 6 dias & 8 dias \\
\hline 2 dias & & 0,4449 & 0,0012 & 0,0000 \\
4 dias & 0,4449 & & 0,0000 & 0,0000 \\
6 dias & 0,0012 & 0,0000 & & 0,0000 \\
8 dias & 0,0000 & 0,0000 & 0,0000 & \\
\hline
\end{tabular}

APÊNDICE N - Níveis descritivos para Comparações múltiplas pelo método de Tukey Contagem - Longo prazo - G IV ao longo do tempo (as diferenças significativas estão hachuradas)

\begin{tabular}{l|llll}
\hline & 2 dias & 4 dias & 6 dias & 8 dias \\
\hline 2 dias & & 0,6460 & 0,0020 & 0,1875 \\
4 dias & 0,6460 & & 0,3829 & 1,0000 \\
6 dias & 0,0020 & 0,3829 & & 0,8762 \\
8 dias & 0,1875 & 1,0000 & 0,8762 & \\
\hline
\end{tabular}


APÊNDICE O - Níveis descritivos para Comparações múltiplas pelo método de Tukey Contagem - Longo prazo - grupos no momento 2 dias (as diferenças significativas estão hachuradas)

\begin{tabular}{l|llll}
\hline Grupo & Controle- & & & \\
\hline Controle-G I & & 0,0061 & 0,8286 & 1,0000 \\
G II & 0,0061 & & 0,0001 & 0,0138 \\
G III & 0,8286 & 0,0001 & & 0,6460 \\
G IV & 1,0000 & 0,0138 & 0,6460 & \\
\hline
\end{tabular}

APÊNDICE P - Níveis descritivos para Comparações múltiplas pelo método de Tukey Contagem - Longo prazo - grupos no momento 4 dias (as diferenças significativas estão hachuradas)

\begin{tabular}{l|llll}
\hline Grupo & $\begin{array}{l}\text { Controle- } \\
\text { G I }\end{array}$ & G II & G III & G IV \\
\hline Controle-G I & & 0,0001 & 0,2277 & 1,0000 \\
G II & 0,0001 & & 0,0000 & 0,0000 \\
G III & 0,2277 & 0,0000 & & 0,4449 \\
G IV & 1,0000 & 0,0000 & 0,4449 & \\
\hline
\end{tabular}

APÊNDICE Q - Níveis descritivos para Comparações múltiplas pelo método de Tukey Contagem - Longo prazo - grupos no momento 6 dias (as diferenças significativas estão hachuradas)

\begin{tabular}{l|llll}
\hline Grupo & $\begin{array}{l}\text { Controle- } \\
\text { G I }\end{array}$ & G II & G III & G IV \\
\hline Controle-G I & & 0,0000 & 0,0000 & 0,7118 \\
G II & 0,0000 & & 0,0000 & 0,0000 \\
G III & 0,0000 & 0,0000 & & 0,0000 \\
G IV & 0,7118 & 0,0000 & 0,0000 & \\
\hline
\end{tabular}

APÊNDICE R - Níveis descritivos para Comparações múltiplas pelo método de Tukey Contagem - Longo prazo - grupos no momento 8 dias (as diferenças significativas estão hachuradas)

\begin{tabular}{|c|c|c|c|c|}
\hline Grupo & $\begin{array}{l}\text { Controle- } \\
\text { G I }\end{array}$ & $G \|$ & G III & G IV \\
\hline Controle-G I & & 0,0000 & 0,0000 & 0,0001 \\
\hline G ॥ & 0,0000 & & 0,9979 & 0,0000 \\
\hline G III & 0,0000 & 0,9979 & & 0,0000 \\
\hline G IV & 0,0001 & 0,0000 & 0,0000 & \\
\hline
\end{tabular}


ANEXO A - Parecer do comitê de ética:

\author{
UNIVERSIDADE DE SĀO PAULO \\ FACULDADE DE ODONTOLOGIA
}

PARECER $n^{\circ} 88 / 03$

Protocolo $79 / 03$

O grupo de Trabalho indicado pelo Comitê de Ética em Pesquisa, APROVOU o protocolo de pesquisa "Avaliação in vitro da citotoxicidade do Alendronato sódico sobre fibroblastos de ligamento periodontal de humanos em cultura celular' de responsabilidade da pesquisadora Vera de Fátima Padrăo Correia, sob orientação do Professor Doutor Celso Luiz Caldeira.

Tendo em vista a legislaçāo vigente, devem ser encaminhados a este Comitê relatórios referentes ao andamento da pesquisa em 13 de novembro de 2003 e em 13 de maio de 2004. Ao término da pesquisa, cópia do trabalho em "cd" ou "disquete", deve ser encaminhada a este CEP.

São Paulo, 13 de maio de 2003

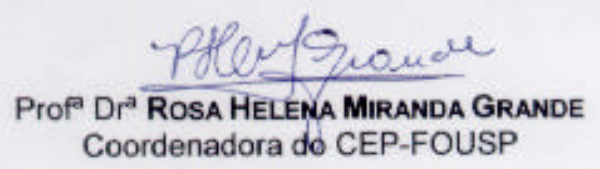

Av. Prot. Lineu Prestes, 2227 - Cidade Universitaria "Armando de Salles Oliveira - CEP 05503-900 Sào PauloisP. TeliFax (011) 3814-0062 